\title{
PARP Inhibitors in Ovarian Cancer: The Route to "Ithaca"
}

\author{
Stergios Boussios ${ }^{1,2, * \mathbb{D}}$, Afroditi Karathanasi ${ }^{1}$, Deirdre Cooke ${ }^{1}$, Cherie Neille ${ }^{1}$, \\ Agne Sadauskaite ${ }^{3}$, Michele Moschetta ${ }^{4}$, Nikolaos Zakynthinakis-Kyriakou ${ }^{5}$ and \\ Nicholas Pavlidis ${ }^{6}$
}

1 Acute Oncology Assessment Unit, Medway NHS Foundation Trust, Windmill Road, Gillingham, Kent ME7 5NY, UK; a.karathanasi@nhs.net (A.K.); deirdrecooke@nhs.net (D.C.); cherie.neill@nhs.net (C.N.)

2 AELIA Organization, 9th Km Thessaloniki-Thermi, 57001 Thessaloniki, Greece

3 Department of Pharmacy, Medway NHS Foundation Trust, Windmill Road, Gillingham, Kent ME7 5NY, UK; agne.sadauskaite@nhs.net

4 Drug Development Unit, Sarah Cannon Research Institute, 93 Harley Street, London W1G 6AD, UK; michelemoschetta1@gmail.com

5 Leicester Diabetes Research Centre, Gwendolen Road, Leicester LE5 4PW, UK; nikolaoszakynthinakis@gmail.com

6 Medical School, University of Ioannina, Stavros Niarchou Avenue, 45110 Ioannina, Greece; npavlid@uoi.gr

* Correspondence: stergiosboussios@gmail.com or stergios.boussios@nhs.net; Tel.: +30-693-86-25-210 or +44-796-03-82-149

Received: 22 April 2019; Accepted: 16 May 2019; Published: 18 May 2019

\begin{abstract}
Poly (ADP-ribose) polymerase (PARP) inhibitors are a novel class of therapeutic agents that target tumors with deficiencies in the homologous recombination DNA repair pathway. Genomic instability characterizes high-grade serous ovarian cancer (HGSOC), with one half of all tumors displaying defects in the important DNA repair pathway of homologous recombination. Early studies have shown significant efficacy for PARP inhibitors in patients with germline breast related cancer antigens 1 and 2 (BRCA1/2) mutations. It has also become evident that $B R C A$ wild-type patients with other defects in the homologous recombination repair pathway benefit from this treatment. Companion homologous recombination deficiency (HRD) scores are being developed to guide the selection of patients that are most likely to benefit from PARP inhibition. The choice of which PARP inhibitor is mainly based upon the number of prior therapies and the presence of a BRCA mutation or HRD. The identification of patients most likely to benefit from PARP inhibitor therapy in view of HRD and other biomarker assessments is still challenging. The aim of this review is to describe the current evidence for PARP inhibitors in ovarian cancer, their mechanism of action, and the outstanding issues, including the rate of long-term toxicities and the evolution of resistance.
\end{abstract}

Keywords: ovarian cancer; $B R C A$; PARP inhibitors; homologous recombination; companion diagnostic; toxic effects; resistance mechanism

\section{Introduction}

Ovarian cancer is composed of three histological subtypes: epithelial (90\%), germ cell (5\%), and sex cord stromal cell (5\%). Epithelial ovarian cancer (EOC) is the most lethal gynecological disease due to lack of screening test sensitivity [1]. Histologic subtypes of EOC include high- and low-grade serous $(75-80 \%)$, mucinous (3\%), endometrioid $(10 \%)$, and clear cell (10\%) [2]. Typically, EOC is diagnosed being progressed to an advanced stage with the involvement of the peritoneal cavity and other organs [3]. Consequently, the prognosis of the disease is dismal. 
Current first-line treatment of high-grade EOC includes debulking surgery, followed by platinum-based doublet chemotherapy. Although the disease is chemo-sensitive, most patients will eventually experience disease recurrence, following the initial remission. Poly (ADP-ribose) polymerase (PARP) inhibitors have entered into standard treatment for EOC, based on the results from randomized clinical trials demonstrating the significant prolongation of progression-free survival (PFS), accompanied by acceptable tolerability. Olaparib and rucaparib have currently been approved for the treatment of recurrent BRCA mutant ovarian cancer, as well as maintenance therapy in platinum-sensitive relapsed disease, whereas niraparib is only indicated for the maintenance setting. Other newer agents, such as talazoparib and veliparib, are in earlier stages of development. In the era of precision medicine, $B R C A$ and homologous recombination deficiency (HRD) status represent novel predictive biomarkers of response to chemotherapy and PARP inhibitors [4]. Germline mutations of the genes $B R C A 1 / 2$ are related to increased cancer predisposition and they account for approximately $14 \%$ of EOCs [5]. These genes encode proteins with a crucial role in the repair of double-strand DNA breaks (DSBs) through HRD. Furthermore, somatic mutations and epigenetic inactivation of $B R C A 1 / 2$ have been implicated in sporadic ovarian cancer [6]. Beyond BRCA1/2, additional genes are involved in homologous recombination DNA repair. From the clinical point of view, the efficacy of PARP inhibitors includes both germline BRCA-mutated ovarian cancer and sporadic ovarian cancers with HRD [7].

It took more than 10 years from the discovery of the synthetic lethality upon PARP inhibition to the regulatory approval of PARP inhibitors. Taken the significant improvement in patients' benefit observed in earlier therapeutic settings, along with the likelihood of long-term tolerability of PARP inhibitors, there is great potential for this drug class to become a foundation treatment for ovarian cancer, and far beyond BRCA1/2 mutant tumors.

The purpose of this article is to provide perspective, in the background of various PARP inhibitors for recurrent ovarian cancer treatment, their mechanism of action, tumors' genomic profiling, accompanied by companion diagnostics, tolerance, and potential resistance mechanisms to PARP inhibitor therapy.

\section{PARPs Inhibitors}

PARP inhibitors have changed the therapeutic strategy of patients with $B R C A$-related ovarian cancer [8]. These agents have many similarities, but at the same time notable differences, which are based on the differences between their chemical structural features [9]. All of the PARP inhibitors that were developed in EOC are PARP-1 and PARP-2 inhibitors, while olaparib and rucaparib additionally inhibit PARP-3. Furthermore, rucaparib inhibits tankyrase-1, which is another member of the PARP family [10]. Currently, novel agents are in clinical development. Tables 1-5 resume clinical trials of PARPs inhibitors for treatment of ovarian cancer.

\section{Olaparib}

Olaparib is the first inhibitor of the PARP enzymes 1, 2, and 3 (PARP-1, PARP-2, and PARP-3 respectively) developed in ovarian cancer. It has been approved by both European Medicines Agency (EMA) and United States (US) Food and Drug Administration (FDA) as maintenance treatment for recurrent EOC, fallopian tube, or primary peritoneal cancer, following complete or partial response to chemotherapy with a platinum compound in patients with somatic or germline mutations in BRCA1/2.

Study 19 was a randomized, double-blind, placebo- controlled, phase II study of the use of olaparib as maintenance treatment in the setting of recurrent, platinum sensitive EOC [11]. The patients were eligible, regardless of $B R C A$ mutation status, and they should have been treated with two or more prior lines of platinum based therapy with complete or partial response to their most recent platinum regimen. Two hundred sixty-five patients were enrolled and randomized to olaparib $400 \mathrm{mg}$ bid or placebo. Those that were treated with olaparib had a significantly prolonged PFS (8.4 months vs. 4.8 months, hazard ratio (HR) $0.35 ; 95 \%$ confidence interval (CI) $0.25-0.49 ; p<0.001$ ). This PFS advantage was prominent in all subgroup analyses. A retrospective preplanned analysis of the data by $B R C A$ 
mutation status revealed significant improvement in PFS in patients with either germline, or somatic $B R C A$ mutations that were treated with olaparib as compared with placebo (11.2 vs. 4.3 months, HR $0.18 ; p<0.0001$ ) [12]. However, there is a proportion of patients without a BRCA mutation that may also benefit from olaparib (7.4 vs. 5.5 months, HR 0.54; $p=0.0075)$. This PFS advantage was similar in a subgroup analysis of the $10 \%$ of patients with a somatic rather than germline $B R C A$ mutation (HR 0.23 vs. 0.17 in somatic vs. germline $B R C A$ mutations, respectively) [13]. Importantly, olaparib prolonged the time to second subsequent therapy in both $B R C A$-mutated $(\mathrm{HR} 0.44 ; p<0.001)$ and non- $B R C A$-mutated patients (HR 0.64; $p<0.34$ ), which suggested that treatment with PARP inhibitors did not affect further response to chemotherapy [12]. This evidence confirmed the hypothesis that HRD and consequent susceptibility to platinum compounds or even other drugs that either create DNA damage, such as pegylated liposomal doxorubicin, or prevent damage repair, like PARP inhibitors, depend on various gene alteration beyond BRCA mutation [14]. Following the results of Study 19, the EMA approved olaparib for maintenance treatment of patients with platinum-sensitive relapsed BRCA-mutated HGSOC who responded to platinum-based chemotherapy.

In December 2014, olaparib also received FDA-approval, for use in patients with germline $B R C A$-mutated HGSOC, fallopian tube, or primary peritoneal carcinoma following three or more prior lines of treatment. This was based on the results of Study 42, evaluated olaparib in the dosage of $400 \mathrm{mg}$ bid in heavily pretreated patients with recurrent, platinum resistant ovarian cancer, and a germline $B R C A 1 / 2$ mutation, until disease progression or unacceptable toxicity [15]. The overall response rate (ORR) in BRCA-mutated ovarian cancer was $34 \%$ (range $26 \%-42 \%$ ) with a median duration of response of 7.9 months (5.6-9.6 months).

More recently, the international phase III SOLO2 study evaluated olaparib as maintenance therapy in platinum-sensitive, relapsed ovarian cancer patients with a BRCA1/2 mutation treated with at least two lines of previous chemotherapy [16]. Two hundred ninety-five patients were randomized to receive 2:1 olaparib tablets $300 \mathrm{mg}$ orally bid or placebo after at least four cycles of platinum based regimens. Maintenance therapy with olaparib demonstrated a dramatic improvement in PFS of 19.1 months versus 5.5 months (HR 0.3; 95\% CI 0.22-0.41) in treated patients using $300 \mathrm{mg}$ (two tablets) bid formulation [16]. The results of SOLO2 confirmed Study 19. In view of these data, the FDA recently granted a second therapeutic indication on August 17, 2017, for maintenance following a complete or partial response to platinum-based chemotherapy, regardless $B R C A$ mutation status. Subsequently, EMA approved olaparib in maintenance setting in May 2018, based on the multicenter, randomized, double blinded phase III SOLO-1 trial [17]. The final results were presented at the European Society for Medical Oncology 2018 Congress. Four hundred fifty-one BRCA1/2 mutated patients were randomized in a 2:1 ratio to first-line maintenance with olaparib $300 \mathrm{mg}$ bid or placebo. The median PFS for patients on the placebo arm was only 13.8 months, while the median PFS for those that were treated with olaparib was not reached, but looks to be approximately three years longer than the placebo group (HR 0.30; $p<0.0001$ ) [17]. Table 1 summarizes olaparib clinical trial data. 
Table 1. Clinical trials results for Olaparib in ovarian cancer (OC).

\begin{tabular}{|c|c|c|c|c|c|c|}
\hline Study Ref. & Treatment Arms & PTS & Phase & Setting & ORR Median PFS & $p$-Value \\
\hline STUDY 19 [11] & $\begin{array}{l}\text { Arm1: Olaparib } 400 \text { mg BID } \\
\text { Arm2: Placebo }\end{array}$ & 265 & II & $\begin{array}{l}\text { 1. Platinum-sensitive recurrent } \\
\text { HGSOC, primaryperitoneal or } \\
\text { fallopian tube cancer } \\
\text { 2. Unselected for BRCA status } \\
\text { 3. Maintenance treatment }\end{array}$ & $\begin{array}{l}\text { 1. ORR } 12 \text { vs. } 4 \% \text { (OR 3.36) } \\
\text { 2. Median PFS Overall population: } 8.4 \\
\text { vs. } 4.8 \mathrm{M} \text { (HR 0.35) } \\
\text { BRCAmut: } 11.2 \text { vs. } 4.3 \mathrm{M} \text { (HR } 0.18) \\
\text { BRCAwt: } 7.4 \text { vs. } 5.5 \mathrm{M} \text { (HR } 0.54)\end{array}$ & $\begin{array}{l}p=0.12 \\
p<0.001 \\
p<0.0001 \\
p=0.0075\end{array}$ \\
\hline STUDY 42 [15] & Olaparib 400 mg BID & 193 & II & $\begin{array}{l}\text { 1. Recurrent pre-treated advanced } \\
\text { OC, primary peritoneal or } \\
\text { fallopian tube cancer } \\
\text { 2. } g B R C A 12 \mathrm{mut}\end{array}$ & $\begin{array}{c}\text { 1. ORR } 34 \% \text { (3+ prior regimens), } 31.1 \% \\
\text { (overall) } \\
\text { 2. Median PFS: } 7.9 \mathrm{M}\end{array}$ & \\
\hline SOLO 2 [16] & $\begin{array}{c}\text { Arm1: Olaparib } 300 \text { mg BID } \\
\text { Arm2: Placebo }\end{array}$ & 295 & III & $\begin{array}{l}\text { 1. Platinum-sensitive recurrent } \\
\text { HGSOC or HGEOC, primary } \\
\text { peritoneal or fallopian tube cancer } \\
\text { 2. gBRCA1 } 2 m u t \\
\text { 3. Maintenance treatment }\end{array}$ & Median PFS: 19.1 vs. $5.5 \mathrm{M}$ & $p<0.0001$ \\
\hline SOLO 1 [17] & $\begin{array}{c}\text { Arm1: Olaparib } 300 \text { mg BID } \\
\text { Arm2: Placebo }\end{array}$ & 451 & III & $\begin{array}{l}\text { 1. Platinum sensitive after first line } \\
\text { platinum based } C T \\
\text { 2. } \mathrm{g} B R C A 1 / 2 \\
\text { 3. Maintenance treatment }\end{array}$ & Median PFS: NR vs. $13.8 \mathrm{M}$ & $p<0.001$ \\
\hline Fong, P.C.; et al. [18] & Olaparib 200 mg BID & 60 & $\mathrm{I}$ & & Radiological and or CA125 response $40 \%$ & \\
\hline $\begin{array}{l}\text { Audeh, M.W.; et al. } \\
\text { [19] }\end{array}$ & $\begin{array}{l}\text { Arm1: Olaparib } 400 \mathrm{mg} \text { BID } \\
\quad(n=33) \\
\text { Arm2: Olaparib } 100 \mathrm{mg} \text { BID } \\
\quad(n=24)\end{array}$ & 57 & II & Recurrent $B R C A$-mutated OC & $\begin{array}{l}\text { 1. ORR } \\
33 \text { vs. } 13 \% \\
\text { 2. Median PFS: } \\
5.8 \text { vs. } 1.9 \mathrm{M}\end{array}$ & \\
\hline $\begin{array}{l}\text { Gelmon, K.A.; et al. } \\
\text { [20] }\end{array}$ & Olaparib 400 mg BID & 64 & & $\begin{array}{l}\text { 1. Recurrent } B R C A \text {-mutated } \mathrm{OC} \\
\text { 2. Known } B R C A \text { status }\end{array}$ & $\begin{array}{l}\text { 1. ORR, BRCAmut: } 41 \%, B R C A w t: 24 \% \\
\text { 2. Median PFS, BRCAmut: } 7.3 \mathrm{M} \text {, } \\
\text { BRCAwt: } 6.3 \mathrm{M}\end{array}$ & \\
\hline STUDY 12 [21] & $\begin{array}{l}\text { Arm1: Olaparib } 400 \mathrm{mg} \text { BID } \\
\text { Arm2: Olaparib } 200 \mathrm{mg}^{\mathrm{BID}} \\
\text { Arm3: PLD 50mg m² }\end{array}$ & 97 & II & $\begin{array}{l}\text { 1. Recurred within } 12 \mathrm{M} \mathrm{OC} \\
\text { 2. Confirmed } g B R C A 12\end{array}$ & $\begin{array}{l}\text { 1. ORR, } 31 \text { vs. } 25 \text { vs. } 18 \% \\
\text { 2. Median PFS, Olaparib 200: } 6.5 \mathrm{M} \text {, } \\
\text { Olaparib 400: } 8.8 \mathrm{M} \text {, PLD: } 7.1 \mathrm{M}\end{array}$ & $\begin{array}{l}p=0.31 \\
p<0.66\end{array}$ \\
\hline Liu, J.F.; et al. [22] & $\begin{array}{c}\text { Arm1: Olaparib } 200 \mathrm{mg} \\
\text { BID + cediranib } 30 \mathrm{mg} \text { OD } \\
\text { Arm2: } \\
\text { Olaparib } 400 \mathrm{mg} \text { BID }\end{array}$ & 90 & II & $\begin{array}{l}\text { 1. Platinum-sensitive recurrent } \\
\text { HGSOC HGEOC } \\
\text { 2. Unselected for BRCA status }\end{array}$ & $\begin{array}{c}\text { 1. ORR } \\
\text { 79.6 vs. } 47.8 \% \text { (OR } 4.24) \\
\text { 2. Median PFS } \\
\text { 17.7 vs. 9M (HR 0.42) } \\
\text { BRCAmut } 19.4 \text { vs. } 16.5 \mathrm{M} \text { (HR } 0.55) \\
\text { BRCAwt } 16.5 \text { vs. } 5.7 \mathrm{M} \text { (HR } 0.32)\end{array}$ & $\begin{array}{l}p=0.002 \\
p=0.005 \\
p=0.16 \\
p=0.008\end{array}$ \\
\hline
\end{tabular}


Table 1. Cont

\begin{tabular}{|c|c|c|c|c|c|c|}
\hline Study Ref. & Treatment Arms & PTS & Phase & Setting & ORR Median PFS & $p$-Value \\
\hline STUDY 41 [23] & $\begin{array}{c}\text { Arm1: Carboplatin AUC4 D1, } \\
\text { paclitaxel } 175 \mathrm{mg} \mathrm{m}^{2} \mathrm{D} 1 \text {, olaparib } \\
200 \mathrm{mg} \text { BID D1-10 every 21D } \\
\text { followed by olaparib } 400 \mathrm{mg} \text { BID } \\
\text { maintenance } \\
\text { Arm2: carboplatin AUC6 D1, } \\
\text { paclitaxel } 175 \mathrm{mg} \mathrm{m}{ }^{2} \text { every 21D }\end{array}$ & 162 & II & $\begin{array}{c}\text { Platinum sensitive recurrent } \\
\text { HGSOC }\end{array}$ & $\begin{array}{l}\text { 1. ORR: } 64 \text { vs. } 58 \% \\
\text { 2. Median PFS: } 12.2 \text { vs. } 9.6 \mathrm{M} \text { (HR } 0.51)\end{array}$ & $p=0.0012$ \\
\hline $\begin{array}{c}\text { SOLO3, } \\
\text { NCT02282020 [24] }\end{array}$ & $\begin{array}{l}\text { Arm1: Olaparib } 300 \text { mg BID } \\
\text { Arm2: Physician's choice CT }\end{array}$ & 266 & III & $\begin{array}{c}\text { 1. Recurrent, platinum-sensitive } \\
\text { OC } \\
\text { 2. } g B R C A 12 \\
\text { 3. } 2+\text { prior regimens }\end{array}$ & PFS (ongoing study) & \\
\hline $\begin{array}{l}\text { OReO, NCT03106987 } \\
{[25]}\end{array}$ & $\begin{array}{l}\text { Arm1: Olaparib } 300 \text { mg BID } \\
\text { Arm2: Placebo }\end{array}$ & & $\mathrm{IIIb}$ & $\begin{array}{l}\text { Recurrent, platinum-sensitive OC } \\
\text { 2. Previously treated withPARP } \\
\text { inhibitor } \\
\text { 3. Unselected for } B R C A \text { status } \\
\text { 4. Maintenance treatment }\end{array}$ & PFS (ongoing study) & \\
\hline $\begin{array}{c}\text { PAOLA-1, } \\
\text { NCT02477644 [26] }\end{array}$ & $\begin{array}{c}\text { Arm1: Olaparib } 300 \mathrm{mg} \text { BID } \\
\text { Arm2: Placebo (in addition to } \\
\text { bevacizumab) }\end{array}$ & 612 & III & $\begin{array}{l}\text { 1. Newly-diagnosed OC } \\
\text { 2. PR or CR to platinum CT with } \\
\text { bevacizumab } \\
\text { 3. Planned bevacizumab } \\
\text { maintenance } \\
\text { 4. Unselected for } B R C A \text { Status } \\
\text { 5. Maintenance treatment }\end{array}$ & PFS (ongoing study) & \\
\hline $\begin{array}{c}\text { COCOS, } \\
\text { NCT02502266 [27] }\end{array}$ & $\begin{array}{c}\text { Arm1: Olaparib } \\
\text { Arm2: Cediranib } \\
\text { Arm3: Olaparib + cediranib } \\
\text { Arm4: Physician's choice CT }\end{array}$ & 680 & II III & $\begin{array}{l}\text { 1. Recurrent, platinum-resistant } \\
\text { OC } \\
\text { 2. gBRCA1 } 2 \\
\text { 3. 1-3 prior regimens }\end{array}$ & OS (ongoing study) & \\
\hline NCT02446600 [28] & $\begin{array}{c}\text { Arm1: Olaparib } \\
\text { Arm2: Olaparib + cediranib } \\
\text { Arm3: Physician's choice CT }\end{array}$ & 549 & III & $\begin{array}{l}\text { 1. Recurrent, platinum-sensitive } \\
\text { OC } \\
\text { 2. } g B R C A 12 \\
\text { 3. Unselected for } B R C A \text { status }\end{array}$ & PFS (ongoing study) & \\
\hline NCT01116648 [29] & $\begin{array}{c}\text { Arm1: Cediranib } 30 \mathrm{mg}+\text { olaparib } \\
200 \mathrm{mg} \text { BID } \\
\text { Arm2: Olaparib } 400 \mathrm{mg} \text { BID }\end{array}$ & 162 & I II & $\begin{array}{l}\text { Recurrent Papillary-Serous } \\
\text { Ovarian, Fallopian Tube, or } \\
\text { Peritoneal Cancer }\end{array}$ & ORR: $44 \%$ & \\
\hline
\end{tabular}

Ref: reference; PTS: patients; BID: twice a day; HGSOC: high-grade serous ovarian cancer; HR: hazard ratio; OC: ovarian cancer; HGEOC: high-grade endometrioid cancer; $B R C A$ mut: $B R C A$ mutated. CT: chemotherapy; PFS: progression free survival; M: months; ORR: objective response rate; OR: odds ratio; gBRCAmut: germline $B R C A$ mutated; $B R C A$ wt: $B R C A$ wild type; NR: not reached; PR: partial response; CR: complete response; OS: overall survival; AUC: area under the curve; D: days. 


\section{Niraparib}

Niraparib is a potent and selective inhibitor of PARP-1 and PARP-2. It is primarily metabolized by carboxylesterase to form a major inactive metabolite, which subsequently undergoes glucuronidation. The activity and safety of niraparib monotherapy $300 \mathrm{mg}$ OD were initially assessed in the phase I trial, including 42 patients with relapsed ovarian cancer [30]. Pharmacodynamic analyses confirmed that PARP inhibition exceeded $50 \%$ at daily doses that were greater than $80 \mathrm{mg}$ and antitumour activity was confirmed beyond doses of $60 \mathrm{mg}$. The ORR in BRCA1/2 mutated patients was $40 \%$, and the relevant median duration of response 12.9 months. Interestingly, an ORR of $67 \%$ was achieved in platinum-sensitive disease and $B R C A 1 / 2$ wild-type patients. These results are compatible with those that were observed in a double-blind, randomized phase III study, investigating the role of niraparib as maintenance therapy in relapsed ovarian cancer [31]. In this trial, 553 EOC patients were randomized 2:1 to orally niraparib $300 \mathrm{mg}$ QD or matched placebo within eight weeks of the most recent therapy, until progression or unacceptable toxicity. All of the patients had been treated with at least two prior platinum-based regimens. The eligible patients were assigned to one of two cohorts; those with germline $B R C A$ mutations were assigned to the germline $B R C A$ mutated cohort $(n=203)$, whereas patients without germline $B R C A$ mutations were assigned to the non-germline $B R C A$ mutated cohort $(n=350)$. In the primary efficacy analyses, the $B R C A$ wild-type cohort was divided into two subgroups according to HRD status, which were based on companion diagnostic test for HRD. Furthermore, in exploratory analyses, the HRD-positive subgroup was further defined by the presence or a lack of a somatic $B R C A$ mutation, respectively (47 patients HRD-positive somatic $B R C A 1 / 2$ mutated and 115 patients HRD-positive $B R C A$ wild-type). The PFS was independently assessed in the germline $B R C A$ and $B R C A$ wild-type cohort, and it was found to be longer among the niraparib-treated patients in all groups when compared to the placebo. Among germline BRCA mutation carriers, there was a significant prolongation in PFS in the niraparib group as compared to placebo (median PFS 21.0 months vs. 5.5 months, HR $0.27 ; 95 \%$ CI $0.017-0.41 ; p<0.0001$ ). When the HRD tumors were retrospectively assessed in an exploratory analysis out of the non-germline BRCA group, niraparib reduced the risk of progression by $62 \%$ (PFS 12.9 months versus 3.8 months; HR $0.38 ; 95 \%$ CI $0.24-0.59$ ). Non-germline $B R C A$ mutant and negative HRD patients that were treated with niraparib achieved a smaller, but significant, prolongation of PFS when compared to placebo (9.3 months vs. 3.9 months, HR $0.45 ; 95 \%$ CI 0.34-0.61). Furthermore, PFS was longer in the HRD-positive somatic $B R C A 1 / 2$ mutated subgroup, similarly to the germline $B R C A$ cohort (20.9 vs. 11.0 months, HR $0.27 ; p=0.02$ ). In the HRD-positive $B R C A$ wild-type subgroup, PFS was 9.3 and 3.7 months in the niraparib group and in the placebo group (HR 0.38; $p<0.001$ ), respectively. Finally, in the HRD-negative non-germline $B R C A$ mutation subset of patients, the obtained PFS was 6.9 vs. 3.8 months (HR, $0.58 ; 95 \%$ CI $0.36-0.92 ; p=0.02)$.

In March 2017, FDA approved niraparib at a dose of $300 \mathrm{mg}$ daily as maintenance treatment of recurrent EOC, fallopian tube, or primary peritoneal cancer, in responders to platinum-based chemotherapy; the approval of niraparib by EMA, at the same context, came in November 2017. Furthermore, in June 2018, the results of the Quadra Trial were presented at the American Society of Clinical Oncology annual meeting [32]. This was a phase II, open-label study of niraparib in the setting of platinum sensitive, HRD-positive, HGSOC. Among the 45 patients treated with three or more previous regimens without prior PARP inhibitor administration, the achieved ORR was $27.5 \%$ and the duration of response 9.2 months. Finally, PRIMA (NCT02655016) is an ongoing, phase III, randomized, placebo-controlled study of maintenance niraparib in high-risk patients with HRD advanced ovarian cancer, who responded to first-line platinum-based chemotherapy [33]. Table 2 shows a summary of the trials evaluating niraparib use in the recurrent setting. 
Table 2. Clinical trials results for Niraparib in OC.

\begin{tabular}{|c|c|c|c|c|c|c|}
\hline Study Ref. & Treatment Arms & PTS & Phase & Setting & Results & $p$-Value \\
\hline $\begin{array}{c}\text { NOVA/ENGOT-OV16 } \\
{[31]}\end{array}$ & $\begin{array}{l}\text { Arm1: Niraparib } \\
300 \text { mg OD } \\
\text { Arm2: Placebo }\end{array}$ & 553 & III & $\begin{array}{l}\text { 1. Recurrent, platinum-sensitive OC } \\
\text { 2. Any } B R C A 1 / 2 \text { status } \\
\text { 3. At least two prior lines of platinum-based } \\
\text { CT with response to last platinum regimen } \\
\text { 4. Maintenance treatment }\end{array}$ & $\begin{array}{c}\text { Median PFS } \\
\text { gBRCAmut: } 21 \text { vs. } 5.5 \mathrm{M},(\text { HR } 0.27) \\
B R C A \text { wt HRD(+): } 12.9 \text { vs. } 3.8 \mathrm{M}, \\
\text { (HR } 0.38) \\
\text { Overall non-gBRCA: } 9.3 \text { vs. } 3.9 \mathrm{M}, \\
\text { (HR } 0.45)\end{array}$ & $\begin{array}{l}p<0.0001 \\
p<0.00001 \\
p<0.0001\end{array}$ \\
\hline QUADRA [32] & Niraparib $300 \mathrm{mg}$ & 45 & II & $\begin{array}{l}\text { Platinum sensitive } \mathrm{HRD}(+) \mathrm{HGSOC} \text {; } \\
\text { primary peritoneal or fallopian-tube cancer }\end{array}$ & ORR $27.5 \%$, DCR $68.6 \%$ & \\
\hline $\begin{array}{c}\text { PRIMA, NCT0265501 } \\
\text { [33] }\end{array}$ & $\begin{array}{l}\text { Arm1: Niraparib } \\
300 \text { mg OD } \\
\text { Arm2: Placebo }\end{array}$ & 620 & III & $\begin{array}{l}\text { 1. Newly-diagnosed OC } \\
\text { 2. PR or CR to platinum CT } \\
\text { 3. HRD }(+) \\
\text { 4. Maintenance treatment }\end{array}$ & PFS (ongoing study) & \\
\hline
\end{tabular}

Ref: reference; PTS: patients; OD: once a day; HGSOC: high grade serous ovarian cancer; OC: ovarian cancer; $B R C A$ mut: $B R C A$ mutated; CT: chemotherapy; HRD(+): homologous recombination deficiency positive; $\mathrm{HRD}(-)$ : homologous recombination deficiency negative; PFS: progression free survival; M: months; ORR: objective response rate; DCR: disease control rate; gBRCAmut: germline $B R C A$ mutated; $B R C A w t: B R C A$ wild type; HR: hazard ratio; PR: partial response; CR: complete response. 


\section{Rucaparib}

Rucaparib is a potent PARP-1 and PARP-2 oral inhibitor, which is approved by FDA in December 2016 and by EMA in May 2018 as monotherapy for the treatment of advanced BRCA-mutated ovarian cancer, relapsed after at least two chemotherapy lines. It differs by other PARP inhibitors, because it inhibits tankyrases that promote homologous recombination [34]. Rucaparib is metabolized by CYP2D6 and, to a lesser extent, by CYP1A2 and CYP3A4. It has been evaluated in two key clinical trials in this setting; the phase I II Study 10 and the phase II trial ARIEL 2. Table 3 summaries additional ongoing clinical trials.

Part 1 of Study 10 (phase I) included 56 patients with advanced solid tumors and established an optimal dose of $600 \mathrm{mg}$ bid, which is characterized by acceptable toxicities. In Part 2A (phase II), 42 patients with recurrent, platinum-sensitive ovarian cancer, and germline $B R C A 1 / 2$ mutations, who were previously treated with two to four lines of chemotherapy, received maintenance rucaparib $600 \mathrm{mg}$ bid [35]. The reported objective response rate was $59.5 \%$ and the median duration of response of 7.8 months (range 5.6-10.5).

The ARIEL 2 study was a multicenter, two-part, phase II open label trial that assessed the efficacy of rucaparib in relapsed HGSOC or endometrioid ovarian carcinoma following one or more (part 1) and three or four prior chemotherapy lines (part 2), independently of the platinum-sensitivity status. ARIEL 2 Part 1 enrolled 192 platinum-sensitive OC patients and stratified the patients into three cohorts [36]; $B R C A 1 / 2$-mutated $(n=40), B R C A$ wild-type with loss of heterozygosity (LOH) high $(n=82)$, and $B R C A$ wild-type with LOH low $(n=70)$. The median PFS was significantly longer in the $B R C A$ mutated subgroup (12.8 months) and in the $B R C A$ wild-type LOH high (5.7 months) when compared to $B R C A$ wild-type $\mathrm{LOH}$ low subgroup (5.2 months). This difference was significant in the $B R C A$ mutant group (HR $0.27 ; 95 \%$ CI $0.16-0.44 ; p<0.0001$ ) when compared to the LOH low group; a similar, though not statistically significant, trend was demonstrated in the LOH high group (HR 0.62; $95 \%$ CI $0.42-0.90 ; p=0.011$ ) as compared to the $\mathrm{LOH}$ low group. There was also a notable advantage in the median duration of response in the BRCA mutant group (9.2 months) and LOH high group (10.8 months) as compared to the LOH low group (5.6 months), whereas, the ORR was higher in the $B R C A 1 / 2$-mutated $(80 \%)$ and in the BRCA wild-type $\mathrm{LOH}$ high (29\%) than the BRCA wild-type $\mathrm{LOH}$ low subgroup $(10 \%)$. Indeed, this study is the first that prospectively demonstrated that the HRD signature could serve as a predictive biomarker for the PARP inhibitor response in BRCA wild-type patients with HGSOC. Interestingly, an analysis of tumor biopsies revealed an association between the methylation of BRCA1 or RAD51C and high $\mathrm{LOH}$, with positive impact on ORR $(52.4 \%$ and $75 \%$, respectively) and PFS (7.4 months and 11.1 months, respectively). However, the establishment of the predictive value of methylation of $B R C A 1$ or $R A D 51 C$ requires further study [37]. The second part of ARIEL 2 trial is still ongoing (NCT01891344); 286 patients who have been treated with at least three instances of chemotherapy and recurred with both platinum sensitive or resistant disease have been enrolled with the prospect to of evaluating the clinical activity of rucaparib based on HRD status [38]. Preliminary data incorporating Parts 1 and 2 demonstrate a difference in PFS among BRCA mutation carriers on the basis of platinum sensitivity $(12.7,7.3$, and 5.0 months in platinum-sensitive, -resistant, and -refractory setting, respectively) [38]. The pooled analysis of the two trials confirmed these encouraging results, including 106 patients with HGSOC and a deleterious BRCA1/2 mutations [39]. Among them, 42 patients participated in Study 10 (Part 2A) and 64 in both parts of ARIEL 2. All of the patients were treated with at least two prior lines of chemotherapy, while $74.5 \%$ exhibited sensitivity to their last platinum-based therapy, $18.8 \%$ were platinum resistant, and $8.4 \%$ platinum refractory. Germline mutations were detected in $83 \%$ all patients, whereas $17 \%$ were carriers of somatic alterations. Among them, BRCA1/2 genes were identified in 63.2 and $36.8 \%$, respectively. The median duration of response was 9.2 months, and no difference in ORR was reported between the BRCA1/2 mutated subgroups. Additionally, patients with a platinum-free interval that exceeded 12 months had a higher ORR than those with a platinum-free interval of 6-12 months or less than six months. 
Table 3. Clinical trials results for Rucaparibin in ovarian cancer.

\begin{tabular}{|c|c|c|c|c|c|c|}
\hline Study Ref. & Treatment Arms & PTS & Phase & Setting & Results & $p$-Value \\
\hline STUDY 10 [35] & $\begin{array}{l}\text { Rucaparib } 600 \mathrm{mg} \\
\text { BID }\end{array}$ & $\begin{array}{c}56+ \\
42\end{array}$ & I II & $\begin{array}{l}\text { 1. Platinum-sensitive recurrent HGSOC or } \\
\text { HGEOC, primary peritoneal or fallopian } \\
\text { tube cancer } \\
\text { 2. gBRCAmut (phase II PART 2A) }\end{array}$ & $\begin{array}{l}\text { ORR: } 59.5 \% \\
\text { MDR:7.8M }\end{array}$ & \\
\hline ARIEL 2 PART 1 [36] & $\begin{array}{l}\text { Rucaparib } 600 \mathrm{mg} \\
\text { BID }\end{array}$ & 192 & II & $\begin{array}{c}\text { 1. Platinum sensitive recurrent HGSOC or } \\
\text { HGEOC, primary peritoneal or fallopian } \\
\text { tube cancer } \\
\text { 2. Any } B R C A \text { mutation status }\end{array}$ & $\begin{array}{c}\text { ORR: BRCAmut } 80 \% \text {, } \\
\text { BRCAwt LOH high 39\%, } \\
\text { BRCAwt LOH low } 13 \% \\
\text { Median PFS: } \\
\text { BRCAmut: } 12.8 \mathrm{M} \\
\text { BRCAwt LOH High: } 5.7 \mathrm{M} \\
\text { BRCAwt LOH low: } 5.2 \mathrm{M}\end{array}$ & $\begin{array}{c}p<0.0001 \\
p=0.011\end{array}$ \\
\hline ARIEL 3 [40] & $\begin{array}{l}\text { Arm1: Rucaparib } \\
600 \text { mg BID } \\
\text { Arm2: Placebo }\end{array}$ & 564 & III & $\begin{array}{c}\text { 1. Platinum-sensitive recurrent HGSOC or } \\
\text { HGEOC, primary peritoneal or fallopian } \\
\text { tube cancer } \\
\text { 2. Any } B R C A \text { mutation Status } \\
3 . \geq 2 \text { prior lines of } C T \\
\text { 4. Maintenance treatment }\end{array}$ & $\begin{array}{c}\text { Median PFS: } \\
\text { BRCAmut: } 16.6 \text { vs. } 5.4 \mathrm{M} \\
\text { HRD(+): } 13.6 \text { vs. } 5.4 \mathrm{M} \\
\text { ITTP: } 10.8 \text { vs. } 5.4 \mathrm{M}\end{array}$ & $\begin{array}{l}p<0.0001 \\
p<0.0001 \\
p<0.0001\end{array}$ \\
\hline
\end{tabular}

Arm1: rucaparib

ARIEL4 [41] Arm2: 1. Recurrent or progressive ovarian,

platinum-based CT $345^{*} \quad$ III fallopian tube, or primary peritoneal cancer $\quad$ PFS (ongoing study)

(monotherapy or

2. $\geq 2$ prior lines of $\mathrm{CT}$

$$
\text { doublet) }
$$

Ref: reference; PTS: patients; BID: twice a day; HGSOC: high grade serous ovarian cancer; HGEOC: high-grade endometrioid cancer; $B R C A m u t: B R C A$ mutated; CT: chemotherapy;

$\mathrm{HRD}(+)$ : homologous recombination deficiency positive; PFS: progression free survival; M: months; ORR: objective response rate; MDR: median duration of response; $\mathrm{g} B R C A$ mut:

germline BRCA mutated; BRCAwt: BRCA wild type; LOH: loss of heterozygosity; ITTP: intention to treat population; * Estimated enrollment. 
ARIEL 3 is a phase III randomized trial of oral rucaparib $600 \mathrm{mg}$ bid versus placebo (2:1 randomization) as maintenance treatment in 564 patients with platinum-sensitive HGSOC or endometrioid ovarian cancer, in response to their recent platinum-based chemotherapy [40]. The HRD signature that was mentioned in ARIEL 2 is also being prospectively assessed in ARIEL 3. The primary endpoint was the PFS, which was evaluated based on the molecular signatures of $B R C A$ mutations (germline or somatic), HRD-positivity (including BRCA mutant and BRCA wild-type with LOH high), and intent-to-treat (all enrolled patients). As such, for BRCA mutated patients, the median PFS was 16.6 months in the rucaparib arm versus 5.4 months in the placebo group (HR 0.23; $p=0.0001$ ). Similarly, in BRCA wild-type patients, the reported PFS for those with an HRD-positive disease treated with rucaparib was 13.6 months as compared to 5.4 for the placebo group (HR 0.32; $p=0.0001$ ), while, in the intention to treat population, it was 10.8 versus 5.4 months, respectively (HR $0.36 ; p=0.0001$ ). The secondary endpoint of blinded independent central review PFS was also significant for each molecular signature separately: germline BRCA mutation (26.8 months vs. 5.4 months), homologous recombination deficient high $\mathrm{LOH}$ (22.9 months versus 5.5 months), and overall intent-to-treat populations (13.7 months vs. 5.4 months). An exploratory analysis in the $B R C A$ wild-type only revealed a maintained benefit of rucaparib in both the HRD-positive (median PFS 9.7 months, HR 0.44; $p<0.0001$ ) and HRD-negative subsets (median PFS 6.7 months, HR 0.58; $p=0.0049$ ).

Finally, ARIEL 4 (NCT02855944) is an ongoing phase III study, which was designed to compare the efficacy and the safety of rucaparib versus physician's choice of chemotherapy, depending on platinum status, in BRCA1/2 mutated recurrent ovarian cancer following at least two previous lines of systemic treatment [41]. Primary endpoint is PFS with a target enrollment of 345 patients. Rucaparib is also being explored in combination with programmed death-ligand 1 (PD-L1) inhibitor atezolizumab in a phase Ib trial of patients with recurrent, platinum-sensitive ovarian cancer (NCT03101280) [42]. Table 3 lists the randomized studies of rucaparib in ovarian cancer.

\section{Veliparib}

Veliparib is a potent inhibitor of PARP1/2, which was demonstrated in 2007 to have high anti-tumor efficacy when combined with DNA alkylating agents, such as temozolomide and irradiation [43]. Even though evidence supporting the use of veliparib in the treatment of EOC is limited as compared to other PARP inhibitors, there are still several ongoing studies, with veliparib, either as monotherapy, or, combined with chemotherapy.

In GOG 280, a phase II, single-arm trial, veliparib $400 \mathrm{mg}$ bid was administered to 50 BRCA mutated patients with persistent or recurrent ovarian cancer, which were previously treated with up to three prior lines of chemotherapy, until progression or intolerance [44]. The ORR to veliparib was $26 \%$ (90\% CI: $16-38 \%$ ); nevertheless, 31 out of 50 patients (61\%) progressed on treatment, whereas response in the platinum-resistant and platinum-sensitive patients was 20 and $35 \%$, respectively, with a median PFS of 8.2 months (ranging from 0.43 to 19.55 months) and a median OS of 19.7 months (ranging from 2.3 to 19.7 months). A phase I trial evaluated the maximum tolerated dose, pharmacokinetic and pharmacodynamics properties, and clinical response of veliparib [45]. The recommended phase 2 dose was $400 \mathrm{mg}$ bid, whereas the ORR in BRCA mutated, and BRCA wild-type patients was $23 \%$ and $4 \%$, respectively, accompanied by a clinical benefit rate of $58 \%$ and $38 \%$, across all dose levels. A more recent phase I II trial assessed the role of single agent veliparib in patients with germline $B R C A$ mutations, in the setting of platinum sensitive or resistant ovarian cancer. Sixteen participants were enrolled in the phase I study and 32 in the phase II. The maximum tolerated dose was established at $300 \mathrm{mg}$ twice daily. Median PFS and overall survival (OS) for the intention to treat population were 5.6 and 13.7 months, respectively [46].

A phase II trial randomized 72 patients with BRCA-mutated ovarian cancer to oral cyclophosphamide $50 \mathrm{mg}$ daily with or without veliparib $60 \mathrm{mg}$ PO daily. The combination of veliparib with cyclophosphamide did not improve ORR (11.8\% vs. $19.4 \%$, respectively) or median PFS (2.1 months vs. 2.3 months, respectively; $p=0.68$ ) as compared to single agent cyclophosphamide [47]. 
Similarly, no responses were reported in phase I study of veliparib in combination with topotecan [48]. GOG 3005, a double-blind, randomized phase III trial for the evaluation of veliparib as first-line treatment in association with carboplatin and paclitaxel in newly diagnosed patients with stage III IV EOC is currently recruiting participants $(n=1140$; NCT02470585) [49]. The study includes three treatment arms: chemotherapy only, chemotherapy followed by veliparib switch maintenance, and veliparib combined with chemotherapy followed by continuation maintenance.

In a phase I trial, Reiss et al. evaluated the activity of veliparib combined with low-dose fractionated whole abdominal radiation therapy in 32 patients with peritoneal carcinomatosis due to advanced solid tumors. Among them, 18 were patients with EOC, five of whom with BRCA mutations. The reported ORR was only a 3\%, while a stable disease was exhibited by $33 \%$ of patients. Those with $B R C A$ mutated EOC had a PFS of 4.47 months, as compared to 3.58 months for the BRCA wild-type cohort and an OS of 10.15 months versus 7.89 months, respectively. The PFS of the patients with platinum-sensitive disease was 7.92 months, while those with platinum-resistant EOC reached 3.58 months [50]. Table 4 depicts the completed or ongoing randomized studies testing veliparib in recurrent and maintenance setting.

\section{Talazoparib}

Talazoparib is a PARP1/2 inhibitor, which is selective against BRCA1/2 and phosphatase and tensin homolog (PTEN) mutants, enhances the cytotoxic activity of temozolomide, SN-38, and carboplatin [51]. The efficacy of talazoparib in the treatment of ovarian cancer is still under investigation. It initially assessed in a two-stage dose-escalation trial study, with the enrolment of 34 EOC patients, of whom 25 with germline $B R C A$ mutations, all being previously treated with platinum-based chemotherapy [52]. The reported ORR was $42 \%$ and median PFS 36.4 weeks in a well-tolerated dose of $1000 \mu \mathrm{g}$ day. More recently, a phase I study evaluated talazoparib in combination with carboplatin in patients with several solid tumors independently of germline status. Among the 24 participants, two had EOC ( $8 \%$ ), while $20 \%$ identified $B R C A 1 / 2$ mutations. In the subset of $B R C A$ mutated patients, 1 and 2 cases achieved complete and partial responses, respectively, whereas three patients with somatic BRCA mutation maintained a stable disease beyond four months [53].

The benefit of talazoparib has been established in a phase II ABRAZO study in terms of patients specifically with $B R C A$ mutations. Enrolment was restricted to patients with breast cancer and the reported ORR for $B R C A 1$ and $B R C A 2$ mutations carriers was $24 \%$ and $34 \%$, respectively [54]. However, data from phase II or III studies in patients with EOC are still not available. Nevertheless, a phase II trial of talazoparib in recurrent BRCA1/2-mutated ovarian cancer patients, following primary progression on prior PARP inhibitor, has recently been completed (NCT02326844) [55]. It will be interesting to be clarified whether there is a role for further PARP inhibition in this context.

Currently, there are several trials actively recruiting patients evaluating talazoparib either as monotherapy or in combination. With this regard, a phase 1 study assesses the combination with a checkpoint inhibitor (NCT03330405) [56], whereas, a phase II study exploring talazoparib activity in advanced cancers with PTEN mutations or PTEN loss and HRD defect (NCT02286687) [57]. Furthermore, an ongoing phase II randomized study (NCT02836028) evaluates the activity and tolerance of single agent talazoparib versus combination with temozolomide in patients with BRCA-mutated or homologous recombination-deficient relapsed ovarian cancer [58]. Table 5 lists studies of talazoparib in ovarian cancer that have been completed or are currently ongoing. 
Table 4. Clinical trials results for Veliparib in ovarian cancer.

\begin{tabular}{|c|c|c|c|c|c|c|}
\hline Study Ref. & Treatment Arms & PTS & Phase & Setting & Results & $p$-Value \\
\hline GOG 280 [44] & Veliparib 400 mg BID & 50 & II & $\begin{array}{l}\text { 1. Recurrent or progressive ovarian, } \\
\text { fallopian tube, or primary peritoneal cancer } \\
\begin{array}{c}\text { 2. } \leq 3 \text { prior lines of } C T \\
\text { 3. } g B R C A \text { mut }\end{array}\end{array}$ & $\begin{array}{l}\text { ORR } 26 \% \\
\text { PFS } 8.2 \mathrm{M}\end{array}$ & \\
\hline $\begin{array}{c}\text { Steffensen, K.D.; et al. } \\
\text { [46] }\end{array}$ & Veliparib 300 mg BID & $\begin{array}{l}16 \\
32\end{array}$ & I II & $\begin{array}{l}\text { 1. Ovarian, fallopian tube, or primary } \\
\text { peritoneal cancer } \\
\text { 2. Platinum-resistant or intermediate } \\
\text { sensitive relapse } \\
\text { 3. gBRCAmut }\end{array}$ & $\begin{array}{l}\text { ORR } 65 \% \\
\text { PFS } 5.6 \mathrm{M}\end{array}$ & \\
\hline Kummar, S.; et al. [47] & $\begin{array}{l}\text { Arm1: Cyclophosphamide } 50 \mathrm{mg} \text { OD } \\
\text { Arm2: Cyclophosphamide } 50 \mathrm{mg} \text { OD + } \\
\text { veliparib } 60 \mathrm{mg} \text { OD }\end{array}$ & 72 & II & $\begin{array}{l}\text { 1. Recurrent or progressive ovarian, } \\
\text { fallopian tube, or primary peritoneal cancer } \\
\text { 2. } \geq 1 \text { prior lines of } C T \\
\text { 3. } g B R C A \text { mut }\end{array}$ & $\begin{array}{c}\text { PFS: } \\
2.3 \text { vs. } 2.41 \mathrm{M}\end{array}$ & $p=0.68$ \\
\hline $\begin{array}{c}\text { GOG 3005, } \\
\text { NCT02470585 [49] }\end{array}$ & $\begin{array}{l}\text { Arm1: Carboplatin paclitaxel }+ \\
\text { placebo, followed by placebo } \\
\text { Arm2: Carboplatin paclitaxel }+ \\
\text { veliparib, followed by placebo } \\
\text { Arm3: Carboplatin paclitaxel }+ \\
\text { veliparib, followed by veliparib }\end{array}$ & 1140 & III & $\begin{array}{l}\text { 1. Newly-diagnosed HGSOC, fallopian tube, } \\
\text { or primary peritoneal cancer } \\
\text { 2. Any BRCA mutation status } \\
\text { 3. Maintenance treatment }\end{array}$ & PFS (ongoing study) & \\
\hline NCT01113957 [59] & $\begin{array}{l}\text { Arm1: Veliparib + temozolomide } \\
\text { Arm2: PLD }\end{array}$ & 168 & II & Recurrent HGSOC & & \\
\hline
\end{tabular}

Ref: reference; PTS: patients; GOG: Gynecologic Oncology Group; BID: twice a day; HGSOC: high grade serous ovarian cancer; PLD: PEG-liposomal doxorubicin; PFS: progression free survival; M: months; ORR: objective response rate; OD: once a day; gBRCAmut: germline BRCA mutated. 
Table 5. Clinical trials results for Talazoparib in ovarian cancer.

\begin{tabular}{|c|c|c|c|c|c|c|}
\hline Study Ref. & Treatment Arms & PTS & Phase & Setting & Results Primary Objectives & Status \\
\hline $\begin{array}{l}\text { de Bono, J.; et al., } \\
\text { NCT0128698 [52] }\end{array}$ & Talazoparib $1 \mathrm{mg}$ OD & 34 & I & $\begin{array}{l}\text { 1. Platinum-treated HGSOC or HGEOC, } \\
\text { primary peritoneal or fallopian tube cancer } \\
\text { 2. gBRCAmut ( } 2534)\end{array}$ & $\begin{array}{c}\text { ORR: } 42 \% \\
\text { gBRCAmut: } \\
\text { ORR: } 55 \% \text { in platinum-sensitive } \\
\text { ORR: } 20 \% \text { in platinum-resistant } \\
\text { PFS: } 36.4 \mathrm{M}\end{array}$ & Completed \\
\hline NCT0283602 [58] & $\begin{array}{c}\text { Arm1: Talazoparib } \\
1 \mathrm{mg} \text { OD } \\
\text { Arm2: Talazoparib } 1 \mathrm{mg} \\
\text { OD + Temozolomide } \\
37.5 \mathrm{mg} \mathrm{m}^{2} \text { on D1-5 }\end{array}$ & NA & II & $\begin{array}{l}\text { 1. Recurrent HGSOC or HGEOC, primary } \\
\text { peritoneal or fallopian tube cancer } \\
\text { 2. }<3 \text { prior lines of } C T \\
\text { 3. } g B R C A \text { mut, or } s B R C A \text { mut, or } \operatorname{HRD}(+)\end{array}$ & ORR & Ongoing \\
\hline $\begin{array}{c}\text { NCT02316834 } \\
\text { POSITION trial [60] }\end{array}$ & Talazoparib $1 \mathrm{mg}$ OD & 30 & I & $\begin{array}{l}\text { 1. HGSOC, primary peritoneal or } \\
\text { fallopian tube cancer } \\
\text { 2. No prior therapy }\end{array}$ & $\begin{array}{c}\text { Basal levels and effects of talazoparib } \\
\text { on DNA copy number, LOH and } \\
\text { mutation, and level of RNA and } \\
\text { protein expression in homologous } \\
\text { recombination-related pathways } \\
\text { before and after treatment }\end{array}$ & Ongoing \\
\hline
\end{tabular}

Ref: reference; PTS: patients; OD: once a day; HGSOC: high grade serous ovarian cancer; HGEOC: high-grade endometrioid cancer; CT: chemotherapy; PFS: progression free survival; M: months; ORR: objective response rate; gBRCAmut: germline BRCA mutated; sBRCAmut: somatic BRCA mutated; LOH: loss of heterozygosity; DNA: DeoxyriboNucleic Acid; RNA: Ribonucleic Acid; D: days; $\mathrm{HRD}(+)$ : homologous recombination deficiency positive. 


\section{Functional Aspects of PARP1}

PARP1 initiates and modulates multiple DNA repair pathways, and it is thus important for maintaining genomic integrity. Transcriptional regulation by PARP1 involves both ADP-ribosylation-dependent and independent mechanisms. PARP1 might also regulate transcription by modulating the chromatin structure, altering DNA methylation patterns, acting as a co-regulator of transcription factors, and interacting with chromatin insulators [61]. Under physiological conditions, PARP1 ADP-ribosylation activity curiously follows the rhythmic circadian cycle [62].

The interaction between PARP1 and the NF- $\mathrm{KB}$ pathway promotes the production of several pro-inflammatory cytokines, including TNF $\alpha$, IL-6, INF $\gamma$, E-selectin, and ICAM-1 [63]; PARP inhibition attenuates the upregulation of these factors in response to inflammatory stimuli, and in parallel prevents inflammation-associated side effects of cytotoxics [64]. The loss of PARP1 activity inhibits proliferative signaling and metastasis through anti-inflammatory mechanisms [65,66].

PARP1 also regulates the c-Jun N-terminal kinase (JNK) pathway, which is implicated as a driver of both tumor development and treatment response [67]. PARP1 downregulates MAP kinase phosphatase MKP-1 expression and inhibits the survival kinase Akt, both of which activate JNK [68]. Based on that, PARP inhibition could be potentially therapeutically beneficial in ovarian cancer taken the elevated JNK activity. PARP1 inhibitors promote Akt activity and mTOR signaling, which leads to decreased cell death [69].

In addition to the JNK-mediated signaling, extracellular signal-regulated kinases (ERKs) represent a second family of MAP kinases that participate in cell death determination, tumor progression, angiogenesis, and metastasis. ERK activation is pivotal in cancer cell survival through the upregulation of anti-apoptotic proteins and inhibition of caspase activity [70]. The jnhibition of this pathway by targeting ERK or MEK leads to suppression of ovarian tumor growth [71]. Indeed, PARP1 inhibition causes a loss of ERK2 stimulation by decreasing the activity of critical pro-angiogenic factors, including vascular endothelial growth factor (VEGF) and hypoxia inducible factor (HIF).

\section{PARP and Immune-Checkpoint Inhibitor Combinations}

PARP has a well-established proinflammatory role and, in preclinical models, PARP inhibitors attenuate chronic inflammatory and autoimmune conditions [72]. Furthermore, conventional and targeted anticancer therapeutic approaches affect tumor-targeting immune responses. Indeed, the identification of crosstalk between cytotoxic anticancer agents and cancer-associated immunity may increase the effectiveness of combination strategies [73]. PARP inhibition has been shown to lead to the upregulation of PD-L, both in vivo and in vitro. An intrinsic upregulation of PD-L1 may function to inhibit immune responses downstream of PARP inhibitor-mediated priming, and could potentially be overcome through the combination of PARP inhibitor and PD-L1 blockade [74].

In HGSOC, tumors harboring BRCA1/2 mutations demonstrated a higher neoantigen burden, as well as CD3+ and CD8+ tumor-infiltrating lymphocytes. Increased levels of PD-1 and PD-L1 expression on tumor-infiltrating immune cells as compared to homologous recombination proficient tumors indicates that PD-1/PD-L1 inhibitors may be more effective in BRCA1/2-mutated rather than in the homologous recombination proficient HGSOC [75].

Currently, there are available data from three different PARP inhibitor anti-PD-1/L1 combinations. Olaparib durvalumab, and niraparib pembrolizumab combinations were well tolerated, with toxicities that are in line with those that were observed for the relevant agents in monotherapy settings [76-78]. In contrast, tislelizumab pamiparib combination demonstrated an increased rate of hepatic toxicity, which suggests that the tolerability of PARP inhibitor anti-PD-1 L1 combinations is variable [79]. In platinum-resistant ovarian cancer the niraparib pembrolizumab combination demonstrated an ORR of 25\% [78]; this response rate is similar to that of the PARP inhibitor monotherapy in BRCA1/2-mutant patients in this setting [80]. However, it is impressive that the activity of the combination was independent of the DNA damage repair defect status. In relapsed platinum-sensitive disease, 
BRCA1/2-mutant ovarian cancer, the olaparib durvalumab combination demonstrated an ORR of $63 \%$, which is also compatible with the PARP inhibitor monotherapy activity in this setting [80].

\section{Potential Homologous Recombination Pathway Targets}

DNA damage is often during cell cycle, and it can result in either single-strand DNA breaks or DSBs. Consequently, the loss of genome integrity and cell death are occurred if DNA is not correctly repaired [81]. The success of the inhibition of DNA repair pathways in therapy relies on the identification of inhibitors that target repair proteins that are either directly involved in tumorigenesis or have a synthetic lethal relationship with other repair genes [82]. The inhibition of PARP proteins radiosensitizes glioma cells by inhibiting DNA repair. Studies show that PARP inhibitors decreased the colony formation in O-6-methylguanine-DNAmethyltransferase (MGMT) unmethylated glioblastoma multiforme patient derived xenografts. Radiotherapy in glioblastoma multiforme patients' lead to the upregulation of PARP1 mediated repair of DNA damage in glioblastoma cancer stem cells [83]. Furthermore, synthetic lethality is a situation that arises when two nonlethal defects combine and result in cell death [84].

Homologous recombination and non-Homologous End Joining (NHEJ) are the predominant DSBs repair pathways. Homologous recombination is a precise repair mechanism, which is active during phase S-G2 of the cell cycle, which mediates to limit genetic instability [85]. NHEJ is faster than homologous recombination; nevertheless, it is prone to error $[86,87]$. Alternative NHEJ (alt-NHEJ) was originally identified as a backup repair mechanism in the absence of classical NHEJ factors, but recent studies have demonstrated that alt-NHEJ is active, even when NHEJ as well as homologous recombination is available.

Microhomology-mediated end-joining (MMEJ) is a subtype of alt-NHEJ in the G1-phase [88]. Dissecting the mechanisms of MMEJ is of great interest, because of its potential to destabilize the genome through gene deletions and chromosomal rearrangements in cells that are deficient in canonical

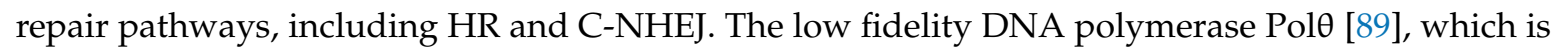
encoded by POLQ, is capable of extending the mismatched termini, ssDNA, and partial ssDNA [90]. Pol $\theta$ and its fly ortholog dmMus 308 have been implicated in the MMEJ of eroded telomeres and DSBs induced by stressed replication forks [91]. In budding yeast, there is no Pol $\theta$ homologue; instead, polymerase delta (Pol反) and Pol4 are important in yeast MMEJ [92]. A recent study showed that BRCA2-deficient ovarian cancer cells express high levels of POLQ, which may contribute to elevated MMEJ in these cells [93]. Therefore, the inhibition of Pol $\theta$ sensitizes these cells to genotoxic chemicals and PARP1 inhibitor treatment, which indicates Pol $\theta$ inhibition as a novel cancer therapeutic strategy.

The first studied homologous recombination proteins were the BRCA1 and 2 [94,95]. Their germline mutations and, consequently, loss of function were associated with the higher risk of breast (ranging from $57 \%$ in $B R C A 1$ mutation to $45 \%$ in $B R C A 2$ mutation) and ovarian cancers (ranging from $11 \%$ in $B R C A 1$ mutation to $40 \%$ in $B R C A 2$ mutation) [96]. Homologous recombination-deficient cancers are potentially sensitive to pharmaceutical agents that induce lesions, which are normally repaired by the homologous recombination pathway. The PARP inhibitors are synthetically lethal in homologous recombination-deficient cells, such as BRCA1/2-mutated tumors [97].

Furthermore, the use of PARP inhibitors following the principles of synthetic lethality may be utilized beyond germline BRCA-mutated ovarian cancer in the context of HRD. The term "BRCAness" describes tumors that have not arisen from a germline $B R C A 1 / 2$ mutation, but, despite that, share certain phenotypes [98]. Several efforts have been made to standardize a test that can optimally identify HRD EOCs. With this regard, transcriptional and mutational signature profiling, proteomics [99] and RNA analyses [100] may identify BRCAness and PARP inhibitor sensitive tumors [98]. In addition, these methods may evaluate the predictive role of prior platinum sensitivity for BRCAness and the subsequent PARP inhibitor responses [18,55]. The limitations of HRD testing include prioritization and the predicted effect of observed mutations, with little emphasis on gene silencing via DNA methylation 
and false positive results. Increased DNA damage not only promotes immune priming through molecular mechanisms, but it also leads to the adaptive upregulation of PD-L1 expression [74].

Beyond BRCA1/2 mutant cells that are highly susceptible to PARP inhibitors, deficiencies in a number of tumour suppressor genes participated in homologous recombination repair, such as ATM ATR (Ataxia-telangiectasia mutated and ATM and RAD3-related), PALB2, CHEK2, BARD1, BRIP1, MRE11, RAD50, NBS1, RAD51C, RAD51D, and the FANC gene family, were also displayed to confer sensitivity to these drugs [98]. With this regard, the accumulation of RAD51 at the DNA lesion is an established marker of homologous recombination proficiency; consequently, its absence following DNA damage has been served as a functional biomarker of homologous recombination dysfunction [101]. As such, the detection of RAD51 foci by immunohistochemistry, demonstrates the predictive factor of response to chemotherapy and PARP inhibition [102]. Many rare diseases are caused by the altered function of DNA damage response genes causing genome instability. Mutations in these genes may have downstream cancer burden that is associated with them. Hence, understanding the biology of rare DNA repair diseases can help to identify novel cancer therapies [103]. The Fanconi Anemia signaling network contains a unique nuclear protein complex that mediates the monoubiquitylation of the FANCD2 and FANCI heterodimer, and coordinates the activities of the downstream DNA repair pathway, including nucleotide excision repair, translesion synthesis, and homologous recombination [104]. In addition, the homozygous deletion of PTEN in 7\% of EOC is proposed to downregulate RAD51, which lead to synthetic lethality upon PARP inhibition [14]. Finally, the amplification of the 11q13 locus resulted in the overexpression of EMSY, which is a suppressor of BRCA2 transcriptional activity in $14 \%$ of EOCs [105].

\section{Combining PARP Inhibition with Companion Diagnostics}

A comprehensive understanding of companion diagnostics for PARP inhibitors is a step forward to personalized treatment, which is based on the power of whole-genome analysis. Companion diagnostics for PARP inhibitors permit optimization of patients' selection with the greatest chance of achieving a response, either in maintenance or recurrent settings.

Currently, there are several available FDA-approved companion diagnostic tests for PARP inhibitors. BRACAnalysis CDx consists of two in vitro assays for germline BRCA1/2 mutational identification; BRACAnalysis CDx Sanger sequencing; and, BRACAnalysis CDx Large Rearrangement Test $\left(\right.$ BART $\left.^{\circledR}\right)$ for sequence variants, and large rearrangements, respectively. Polymerase chain reaction (PCR) and subsequent Sanger sequencing assess exons and exon intron boundaries of BRCA1/2 for single nucleotide polymorphism, insertions $\leq 2$ base pairs (bp), and deletions $\leq 5 \mathrm{bp}$. On the other hand, BART ${ }^{\circledR}$ identifies single- and multi-exon deletions duplications, flanking introns, the Portuguese founder mutation, and proximal promoter sequences, based on multiplex PCR. Variants that were identified by $B R A C$ Analysis $C D x$ require confirmatory analysis by either alternate primer sequencing or PCR analysis, at approximately $1-2 \%$. BRACAnalysis CDx limitations include the detection of deletions $>5 \mathrm{bp}$, insertions $>2 \mathrm{bp}$, RNA transcript processing errors, and finally differentiation between gene duplication and triplication [106].

Myriad's myChoice HRD is an enhancement of BRACAnalysis CDx, taken that it detects both germline and somatic BRCA1/2 mutations together with HRD through its evaluation of genomic scarring. This NGS-based assay creates a genomic scarring composite score (HRD Score), which is a sum of LOH, telomeric allelic imbalance (TAI), and large-scale state transitions (LST). The LOH regions are $\geq 15 \mathrm{Mb}$, but are shorter than chromosomal length [107], whereas TAI determines regions with allelic imbalance that extend to the subtelomere, without crossing the centromere [108]. Taken the confirmed inverse proportion between $B R C A 1$ levels and the number of TAI regions in BRCA1/2 wild-type HGSOC, a high TAI score potentially designates DNA repair defects. Finally, LST evaluates the chromosomal breaks in adjacent regions $\geq 10 \mathrm{Mb}$ after filtering all variation $\leq 3 \mathrm{Mb}$ [109]. The tumors are characterized with a score on a scale of $0-100$, and patients with scores $\geq 42$ are considered to have high HRD [110]. In NOVA study, among the 174 analyzed tumor samples, myChoice HRD identified 
$100 \%$ (68 68) of germline BRCA mutated tumors, and 57\% (61 106) of germline $B R C A$ wild-type patients with HRD [111]. Based on that, myChoice HRD has been approved by FDA to stratify the germline $B R C A 1 / 2$ patients into homologous recombination deficient or proficient cohorts [31].

In contrast to BRACAnalysis CDx, FoundationOneTM utilizes archival formalin-fixed, paraffin-embedded solid tumor samples, and represents the first FDA approved comprehensive genomic profiling analysis for all solid tumours. It involves the parallel DNA sequencing of a panel of 324 genes to detect genomic alterations that may be therapeutically targetable. BRCA1/2, PALB2, FANCM, BARD1, CHK1, ATM, RAD51C, RAD51B, and BLM are genes that could be potentially targeted by the PARP inhibitor [112]. ARIEL 2 and ARIEL 3 trials evaluated the percentage of genomic LOH in tumour samples using the FoundationOne [36,40]. ARIEL 2 utilized a cutoff greater than $14 \%$ to define high LOH; the relevant cutoff that was used by ARIEL 3 was greater than $16 \%$, based on the analysis of LOH from ARIEL 2. Interestingly, in ARIEL 2 trial, BRCA wild-type patients with LOH had improved ORR as compared to those without LOH [ $44 \%$ (95\% CI 33-55\%) versus 20\% (95\% CI 11-31\%), respectively] [36]. This was not the case in ARIEL 3 trial, which demonstrated that LOH status did not alter the clinical benefit in the subset of $B R C A$ wild-type patients [40]. The urgent need for further research in order to be clarified the impact of $\mathrm{LOH}$ on PARP inhibitor response is obvious.

\section{Safety and Tolerability}

The synthetic lethality mechanism of action may have protective effect against severe PARP inhibitor toxicity. However, the consideration of PARP inhibitors induced toxicity is critical, especially in patients that are being treated with multiple lines of chemotherapy. The most common side effects include gastro-intestinal manifestations, myelosuppression, and fatigue. Table 6 depicts the adverse events (AEs) in patients treated with FDA-EMA approved PARP inhibitors.

Gastrointestinal AEs are manageable with dose modification and symptomatic treatment, similarly to the management of chemotherapy-induced gastrointestinal toxicities [113]. In Study 19, the majority of patients experienced at least one $\mathrm{AE}$, mostly grade 12 , with nausea $(68 \%$ vs. $35 \%)$ and vomiting ( $32 \%$ vs. $14 \%$ ) being more frequent in the olaparib group. Grade 34 AEs were exhibited in 35.3, and $20.3 \%$ of the olaparib and placebo group, respectively, which led to more frequent dose interruptions ( $27.9 \%$ vs. $8.6 \%)$ and reductions ( $22.8 \%$ vs. $4.7 \%$ ) in the olaparib arm of the study [11]. AEs mostly occurred within the period between the fourth and eighth week following treatment, and they were generally transient. Similarly, nausea, and vomiting were the most common gastrointestinal AEs in Study 42, occurring in 62, and 39\% of patients, respectively [15]. In addition, grade 34 toxicities were more frequent when compared to Study 19 , occurring in $54 \%$ of patients, and they resulted in dose interruption or reduction in $40 \%$ of them. The relevant specific patient populations and treatment indications of each study may explain the different rates of AEs. Indeed, study 19 evaluated maintenance treatment in the setting of platinum-sensitive disease, whereas study 42 the treatment of advanced ovarian cancer in platinum-resistant recurrence. Daily prokinetic and antihistamine (e.g., 5-HT3) drugs are generally effective in the symptom control of nausea. Several antiemetics are available, including metoclopramide, prochlorperazine, phenothiazine, dexamethasone, olanzapine, haloperidol, or lorazepam. On the other hand, neurokinin-1 receptor antagonist aprepitant is a strong CYP3A4 inhibitor that may affect olaparib plasma concentrations, and it is better to be avoided [114]. Additional gastrointestinal symptoms include constipation and diarrhea, treated with senna or polyethylene glycol 3350, and loperamide, respectively. Furthermore, among the three PARP inhibitors, olaparib is associated with the most grade 3 or 4 events of abdominal pain (3\%); however, the differentiation of other causes that are potentially related to the underlying malignancy should be made [115]. Finally, dyspepsia and dysgeusia are more frequent in patients that were treated with rucaparib, as compared to olaparib or niraparib; nevertheless, severe toxicity is rare $(<1 \%)$. The symptomatic management includes proton pump inhibitors that are accompanied by prokinetics, and measures for improvement in oral hygiene, respectively. 
Table 6. United States (US) Food and Drug Administration-European Medicines Agency (FDA-EMA) approved indications for poly (ADP-ribose) polymerase (PARP) inhibitors and relevant adverse events (AEs).

\begin{tabular}{|c|c|c|c|}
\hline & Olaparib & Niraparib & Rucaparib \\
\hline Dosing & $\begin{array}{l}\text { Capsules: } 400 \text { mg BID } \\
\text { Tablets: } 300 \text { mg BID }\end{array}$ & Capsules: 300 mg BID & Tablets: $600 \mathrm{mg}$ BID \\
\hline Pivotal Trial & $\begin{array}{l}\text { STUDY } 19[11] \\
\text { SOLO } 2[16] \\
\text { STUDY } 42[20]\end{array}$ & NOVA TRIAL [31] & $\begin{array}{l}\text { STUDY } 10 \text { [35] } \\
\text { ARIEL } 2 \text { [36] } \\
\text { ARIEL } 3 \text { [40] }\end{array}$ \\
\hline $\begin{array}{l}\text { FDA Approved } \\
\text { Indications }\end{array}$ & $\begin{array}{l}\text { 2014: } \\
\text { 1. Recurrent } g B R C A m u \text {, epithelial ovarian, } \\
\text { fallopian tube, or primary peritoneal cancer, } \\
\text { treated previously with more than } 3 \text { lines of } \\
\text { platinum-based CT. } \\
\text { 2. Capsules formulations. } \\
\text { 2017: } \\
\text { Maintenance therapy for recurrent epithelial } \\
\text { ovarian, fallopian tube, or primary peritoneal } \\
\text { cancer, treated previously with platinum-based CT. } \\
\text { 2. Tablets formulations. }\end{array}$ & $\begin{array}{l}\text { 2017: Maintenance therapy for recurrent } \\
\text { epithelial ovarian, fallopian tube, or } \\
\text { primary peritoneal cancer treated } \\
\text { previously with platinum-based CT. }\end{array}$ & $\begin{array}{l}\text { 2016: } \\
\text { 1. Relapsed or progressive, platinum } \\
\text { sensitive, } g \text { sBRCAmut, epithelial } \\
\text { ovarian, fallopian tube, or primary } \\
\text { peritoneal cancer, treated previously with } \\
2 \text { or more lines of platinum-based CT. } \\
\text { 2. Patients unable to tolerate further } \\
\text { platinum based CT } \\
\text { 2018: } \\
\text { Maintenance therapy for recurrent, } \\
\text { epithelial ovarian, fallopian tube, or } \\
\text { primary peritoneal cancer, treated } \\
\text { previously with platinum-based CT. }\end{array}$ \\
\hline EMA Approved Indications & $\begin{array}{c}\text { 2014: } \\
\text { Maintenance therapy for BRCA mutated, } \\
\text { platinum-sensitive relapsed epithelial ovarian, } \\
\text { fallopian tube, or primary peritoneal cancer. } \\
\text { 2018: } \\
\text { 1. Maintenance therapy for platinum-sensitive } \\
\text { relapsed epithelial ovarian, fallopian tube, or } \\
\text { primary peritoneal cancer, regardless of } B R C A \\
\text { status. } \\
\text { 2. Tablets formulations }\end{array}$ & $\begin{array}{l}\text { 2017: Maintenance therapy for } \\
\text { platinum-sensitive relapsed epithelial } \\
\text { ovarian, fallopian tube, or primary } \\
\text { peritoneal cancer treated previously with } \\
\text { platinum-based CT }\end{array}$ & $\begin{array}{l}\text { 2018: } \\
\text { 1. Relapsed or progressive, platinum } \\
\text { sensitive, } g s B R C A \text { mut, epithelial } \\
\text { ovarian, fallopian tube, or primary } \\
\text { peritoneal cancer, treated previously with } \\
2 \text { or more lines of platinum-based CT. } \\
\text { 2. Patients unable to tolerate further } \\
\text { platinum based CT }\end{array}$ \\
\hline
\end{tabular}


Table 6. Cont.

\begin{tabular}{|c|c|c|c|}
\hline & Olaparib & Niraparib & Rucaparib \\
\hline \multirow{2}{*}{$\begin{array}{l}\text { AEs (all grades, } \geq 40 \% \\
\text { prevalence) }\end{array}$} & \multirow{2}{*}{$\begin{array}{c}\text { SOLO 2: } \\
\text { Anemia } 4 \% \text {, abdominal pain } 2 \% \text {, intestinal } \\
\text { obstruction } 2 \%\end{array}$} & \multirow{2}{*}{$\begin{array}{l}\text { Leukopenia, anemia, nausea, vomiting, } \\
\text { metabolism nutrition, nervous system }\end{array}$} & $\begin{array}{c}\text { ARIEL 2: } \\
\text { Intestinal obstruction } 2 \% \text {, anemia } 4 \%\end{array}$ \\
\hline & & & $\begin{array}{c}\text { ARIEL 3: } \\
\text { Anemia } 4 \% \text {, pyrexia } 2 \% \text {, vomiting } 2 \%, \\
\text { intestinal obstruction } 1 \%\end{array}$ \\
\hline \multirow{4}{*}{ AEs (grade $34, \geq 5 \%$ prevalence) } & \multirow[b]{2}{*}{$\begin{array}{c}\text { Study } 19 \text { : } \\
\text { Fatigue } 6 \% \text {, anemia } 5 \% \text {, nausea } 2 \% \text {, vomiting } 2 \%\end{array}$} & \multirow{4}{*}{$\begin{array}{c}\text { NOVA TRIAL: } \\
\text { Thrombocytopenia } 28 \% \text {, anemia } 25 \% \text {, } \\
\text { neutropenia } 11 \% \text {, hypertension } 8.2 \% \text {, } \\
\text { fatigue } 8.2 \% \text {, nausea } 3.0 \% \text {, abdominal } \\
\text { pain } 1.1 \%\end{array}$} & $\begin{array}{c}\text { STUDY 10: } \\
\text { Fatigue, anemia, elevated AST ALT }\end{array}$ \\
\hline & & & $\begin{array}{c}\text { ARIEL } 2: \\
\text { Anemia } 45 \% \text {, neutropenia } 7 \% \text {, elevated } \\
\text { ALT AST } 13 \% \text {, fatigue } 9 \% \text {, nausea } 4 \% \text {, } \\
\text { abdominal pain } 2 \%, \\
\text { thrombocytopenia } 2 \%\end{array}$ \\
\hline & $\begin{array}{c}\text { SOLO } 2 \text { : } \\
\text { Anemia } 18 \% \text {, neutropenia } 4 \% \text {, fatigue } 4 \% \text {, nausea } \\
3 \% \text {, vomiting } 3 \% \text {, abdominal pain } 3 \% \text {, } \\
\text { thrombocytopenia } 1 \%\end{array}$ & & $\begin{array}{c}\text { ARIEL 3: } \\
\text { Anemia } 19 \% \text {, neutropenia } 7 \% \text {, elevated } \\
\text { ALT AST } 10 \% \text {, fatigue } 7 \% \text {, nausea } 4 \% \text {, }\end{array}$ \\
\hline & $\begin{array}{c}\text { Study } 42 \text { : } \\
\text { Fatigue } 6 \% \text {, anemia } 19 \% \text {, nausea } 0.5 \% \text {, vomiting } \\
3 \%\end{array}$ & & $\begin{array}{c}\text { abdominal pain } 2 \% \\
\text { thrombocytopenia } 5 \%\end{array}$ \\
\hline \multirow{2}{*}{ Changes in dose due to AEs } & \multirow{2}{*}{$\begin{array}{c}\text { SOLO 2: } \\
\text { Dose reductions } 25 \% \text {, discontinuations } 11 \%\end{array}$} & \multirow{2}{*}{$\begin{array}{c}\text { NOVA TRIAL: } \\
\text { Dose reductions } 66.5 \% \text {, discontinuations } \\
14.7 \%\end{array}$} & $\begin{array}{l}\text { ARIEL 2: } \\
\text { Dose reductions 39\%, } \\
\text { discontinuations } 9 \%\end{array}$ \\
\hline & & & $\begin{array}{l}\text { ARIEL 3: } \\
\text { Dose reductions 55\%, } \\
\text { discontinuations } 13 \%\end{array}$ \\
\hline
\end{tabular}

FDA: Food and Drug Administration; EMA: European Medicines Agency; PARP: Poly (ADP-ribose) polymerase; BID: twice a day; gBRCAmut: germline BRCA mutated; g BRCA: germaline $B R C A$ mutated; g sBRCA: germline somatic $B R C A$ mutated; $C T$ : chemotherapy; AEs: adverse events; ALT: alanine aminotransferase; AST: aspartate aminotransferase. 
Haematological toxicities usually occur early following treatment initiation and recovery is reliable a few months later. Anaemia was more pronounced with olaparib and rucaparib until the fifth or sixth cycle, and then plateaus with continued treatment $[16,40]$. In the three available phase 3 maintenance trials, all-grade anaemia has been reported in 44,50 , and $37 \%$ of patients who received olaparib, niraparib, and rucaparib, respectively $[16,31,40]$. Grade 34 AEs were slightly higher for the niraparib treated patients $(25 \%)$, followed by the cohorts of rucaparib and olaparib (19\% for each subset).

Thrombocytopenia of any grade has been described in $61 \%$ of patients that were treated with niraparib, as compared to 28 and $14 \%$ in those that received rucaparib and olaparib, respectively. The relevant grade 34 AEs occurred in 34,5, and 1\% in the niraparib, rucaparib, and olaparib cohort patients, respectively $[16,31,40]$. With this regard, FDA recommends weekly platelet count monitoring during the first month of treatment with niraparib. There is evidence that platelets and baseline bodyweight could serve as predictors of dose adjustments in patients that were treated with niraparib at $300 \mathrm{mg}$ OD [116]. Those with platelet counts of less than $15 \times 10^{4}$ cells $\mathrm{mL}$, or a baseline bodyweight of less than $77 \mathrm{~kg}$ are at higher risk of grade 34 thrombocytopenia during the first month (35\% vs. $12 \%$ ), and may have better tolerance with a starting dose of $200 \mathrm{mg}$ OD.

The development of acute myeloid leukemia (AML) and myelodysplastic syndrome (MDS) in patients that were treated with olaparib is unusual. In Study 19,2.2\% of patients in the olaparib arm developed AML MDS, versus $0.8 \%$ in the placebo arm [12]. Study 42 demonstrated that patients on olaparib arm, who were heavily pre-treated, developed MDS AML. It seems that long term follow up is important in the clarification of this issue [15].

The PARP inhibitors may also elevate creatinine concentrations; nevertheless, this might not always affect the glomerular filtration rate or lead to renal failure. Rucaparib inhibits kidney transporter proteins MATE1 and MATE2-K, which affect the secretion of creatinine [40]. The ARIEL 3 trial demonstrated an increase of creatinine in $15 \%$ of patients in the rucaparib arm, as compared to $2 \%$ in the placebo. Veliparib additionally interacts with the primarily renal uptake transporter OCT2. SOLO2 trial reported grade 12 elevation in creatinine in $11 \%$ of patients that were treated with olaparib, versus $1 \%$ in the placebo group [16]. On the other hand, niraparib was not related to elevated serum creatinine. Overall, dose reductions or interruptions of PARP inhibitor can be avoided if the glomerular filtration rate is not affected; its assessment should be based on radionucleotide scan.

PARP inhibitors are also associated with hypercholesterolemia and hypertransaminasemia. Rucaparib increased cholesterol levels of any grade in $40-84 \%$ of patients; nevertheless, serious AEs of grade 34 hypercholesterolemia were only reported in $2-4 \%$ of patients [36]. The suggested treatment is the initiation of statins with the regular monitoring of liver enzymes [117]. ARIEL 3 demonstrated that $34 \%$ of rucaparib treated patients developed hypertransaminasemia of any grade, which, however, is overall transient. There are also reports for elevation of alanine aminotransferase $(A L T)$ and aspartate aminotransferase (AST) in 36 and $28 \%$ of patients that were treated with niraparib, respectively. In contrast, olaparib is better tolerated with reported incidences of increased ALT and AST of 5 and $2 \%$, respectively.

\section{Resistance}

Advances in the understanding of PARP inhibitors' resistance is of paramount importance, and it may lead to novel insights into basic mechanisms of the DNA damage response. Each PARP inhibitor has separate chemical structure with diverse off-target effects [118]. This indicates that the utilization of a secondary PARP inhibitor could be therapeutically beneficial in a resistant tumor. The restoration of homology-directed DNA repair through secondary reversion mutations is the most common identified mechanism of resistance [119]. Indeed, the restoration of $B R C A$ activity starts from $B R C A$-deficient and chemo-sensitive cells as a result of several mutations that are induced by platinum agents. This initial restored clone expands in the setting of treatment-specific selective pressure [120]. In this context, somatic $B R C A 1 / 2$ mutations were predicted to restore the protein function in the germline $B R C A 1 / 2$ mutated ovarian cancer patients in a study [121]. Among 46 women that were exposed to tumor 
sequencing, $28 \%$ (13 out of $46 ; 95 \%$ CI $17.3-42.6 \%$ ) possessed secondary $B R C A$ mutations that were predicted to restore $B R C A$ function and homologous recombination activity.

Compensatory deleterious mutations have also been detected to confer PARP inhibitor resistance. In contrast to the homologous recombination, NHEJ only involves minor resection of DNA ends at regions of DSB [122]. TP53 binding protein 1 (53BP1) maintains the balance between homologous recombination and NHEJ, and it promotes NHEJ through the inhibition of extensive DNA end-resection that is required for homologous recombination repair [123]. As such, the loss of 53BP1 function by either mutation or downregulation accelerates the BRCA1-independent end-resection and provides PARP inhibitor resistance [124]. It has been demonstrated that the inactivation of downstream factors of 53BP1-mediated repair, typically RIF1 and REV7, also leads to the restoration of DNA end resection, and consequently promotes homology-mediated repair [119]. In vitro studies revealed that the loss of 53BP1 function allows for the partial restoration of homologous recombination in BRCA1-deficient cells and counteracts sensitivity to the PARP inhibitor [125]. Heat shock protein 90 (Hsp90) is a crucial molecular chaperone that functions to correctly fold client proteins, and consequently prevents them from degradation by the ubiquitin-proteasome system. In vivo synergism between an HSP90-inhibitor (AT13387) and olaparib in PARP inhibitor resistant ovarian cancer has been described [126]. Alternatively, the evidence that acquired epigenetic changes, such as hypermethylation promoter of $B R C A 1$, may restore normal BRCA1 protein expression levels [121].

Furthermore, epigenetic silencing or accelerated protein synthesis and degradation could also lead to decreased expression of PARP enzymes, followed by PARP inhibitors resistance [127]. Another mechanism of inherent or acquired resistance is the upregulation of genes encoding p-glycoprotein efflux pumps, related to decrease intracellular drug levels [128]. In a murine breast cancer model, olaparib resulted in initial inhibited tumor growth, which is associated with an impressive increase in the expression of p-glycoprotein efflux pumps. This resistance can be reverted by the $A B C B 1$ inhibitors verapamil, elacridar, and tariquidar [129]. However, toxicity and lack of specificity characterize p-glycoprotein inhibitors.

Additional pharmacologic methods for reversing PARP inhibitor resistance have been investigated. The knockdown of cyclin-dependent kinase 12 (CDK12) resulted in concomitant downregulation of DNA repair proteins, and consequently the development of a "BRCAness" phenotype [130]. There is in vitro evidence that pharmacological inhibition of CDK12 with Dinaciclib reverses acquired PARP inhibitor resistance [131]. Furthermore, it has been shown that the inhibition of cell cycle regulator WEE1 leads cells to enter the S-phase of the cell cycle, and therefore to further the accumulation of DNA DSBs in the context of HRD and PARP inhibition [132]. Overall, a combined inhibition of CDK12 or WEE1 could be a strategy that is recommended for overcoming homologous recombination restored PARP inhibitor resistance.

\section{Conclusions and Future Perspectives}

PARP inhibitors are a new class of biologic agents, which have changed the clinical management of the ovarian cancer, based upon the pre-selection characteristics of the tumors. It has been established that they have improved PFS, although a longer follow-up is required to also assess the prolongation of OS. Numerous clinical trials are ongoing, both for the currently available PARP inhibitors and those that have not yet been approved by the FDA. The analysis of $B R C A$ mutational status represents a step forward to the individualized management of patients with ovarian cancer, and it should be incorporated in their diagnostic approach. Defects in homologous recombination repair seem to confer PARP inhibitors sensitivity. However, the understanding of mechanisms that contribute to clinical PARP inhibitor responses in the absence of HRD is still under investigation. The increased availability of PARP inhibitor treated specimens will potentially provide insight into novel biomarkers and acquired resistance mechanisms. It appears that treatment with PARP inhibitors is effective for patients with either germline, or somatic BRCA1/2 mutations. The future challenge will be the optimal choice of PARP inhibitor at any given time. That demands the design of larger phase III 
trials, with head-to-head comparisons of them. Furthermore, PARP inhibitors have unique AEs that require further evaluation. Usually, toxicity is easily managed with supportive care and dose reduction, or modification. Further research is needed in terms of the combination of PARP inhibitor, with antiangiogenic, immunocheckpoint inhibitors, and cytotoxics as strategies for overcoming resistance mechanisms, potentiating the therapeutic efficacy, and expanding their clinical utility in non-homologous deficient tumors.

Author Contributions: S.B. collected the data and wrote the paper. A.K., D.C., C.N., A.S., M.M. and N.Z.-K. collected the data. N.P. conceived the original idea and supervised the project. All the authors discussed the results and contributed to the final manuscript.

Funding: This research received no external funding.

Conflicts of Interest: The authors declare no conflict of interest.

\section{References}

1. Henderson, J.T.; Webber, E.M.; Sawaya, G.F. Screening for Ovarian Cancer: Updated Evidence Report and Systematic Review for the US Preventive Services Task Force. JAMA 2018, 319, 595-606. [CrossRef] [PubMed]

2. Saber, M.M.; Zeeneldin, A.A.; El Gammal, M.M.; Salem, S.E.; Darweesh, A.D.; Abdelaziz, A.A.; Monir, M. Treatment outcomes of female germ cell tumors: The Egyptian National Cancer Institute experience. J. Egypt. Natl. Cancer Inst. 2014, 26, 103-108. [CrossRef] [PubMed]

3. Jelovac, D.; Armstrong, D.K. Recent progress in the diagnosis and treatment of ovarian Cancer. CA Cancer J. Clin. 2011, 61, 183-203. [CrossRef] [PubMed]

4. Ganguly, B.; Dolfi, S.C.; Rodriguez-Rodriguez, L.; Ganesan, S.; Hirshfield, K.M. Role of Biomarkers in the Development of PARP Inhibitors. Biomark. Cancer 2016, 8, 15-25. [CrossRef] [PubMed]

5. Alsop, K.; Fereday, S.; Meldrum, C.; DeFazio, A.; Emmanuel, C.; George, J.; Dobrovic, A.; Birrer, M.J.; Webb, P.M.; Stewart, C.; et al. BRCA mutation frequency and patterns of treatment response in $B R C A$ mutation-positive women with ovarian cancer: A report from the Australian Ovarian Cancer Study Group. J. Clin. Oncol. 2012, 30, 2654-2663. [CrossRef] [PubMed]

6. $\quad$ Press, J.Z.; De Luca, A.; Boyd, N.; Young, S.; Troussard, A.; Ridge, Y.; Kaurah, P.; Kalloger, S.E.; Blood, K.A.; Smith, M.; et al. Ovarian carcinomas with genetic and epigenetic BRCA1 loss have distinct molecular abnormalities. BMC Cancer 2008, 8, 17. [CrossRef] [PubMed]

7. AlHilli, M.M.; Becker, M.A.; Weroha, S.J.; Flatten, K.S.; Hurley, R.M.; Harrell, M.I.; Oberg, A.L.; Maurer, M.J.; Hawthorne, K.M.; Hou, X.; et al. In vivo anti-tumor activity of the PARP inhibitor niraparib in homologous recombination deficient and proficient ovarian carcinoma. Gynecol. Oncol. 2016, 143, 379-388. [CrossRef]

8. Fong, P.C.; Boss, D.S.; Yap, T.A.; Tutt, A.; Wu, P.; Mergui-Roelvink, M.; Mortimer, P.; Swaisland, H.; Lau, A.; O'Connor, M.J.; et al. Inhibition of poly(ADP-ribose) polymerase in tumors from BRCA mutation carriers. $N$. Engl. J. Med. 2009, 361, 123-134. [CrossRef]

9. Murai, J.; Huang, S.Y.; Das, B.B.; Renaud, A.; Zhang, Y.; Doroshow, J.H.; Ji, J.; Takeda, S.; Pommier, Y. Trapping of PARP1 and PARP2 by Clinical PARP Inhibitors. Cancer Res. 2012, 72, 5588-5599. [CrossRef]

10. Sonnenblick, A.; de Azambuja, E.; Azim, H.A., Jr.; Piccart, M. An update on PARP inhibitors-Moving to the adjuvant setting. Nat. Rev. Clin. Oncol. 2015, 12, 27-41. [CrossRef]

11. Ledermann, J.; Harter, P.; Gourley, C.; Friedlander, M.; Vergote, I.; Rustin, G.; Scott, C.; Meier, W.; Shapira-Frommer, R.; Safra, T.; et al. Olaparib maintenance therapy in platinum-sensitive relapsed ovarian Cancer. N. Engl. J. Med. 2012, 366, 1382-1392. [CrossRef] [PubMed]

12. Ledermann, J.; Harter, P.; Gourley, C.; Friedlander, M.; Vergote, I.; Rustin, G.; Scott, C.L.; Meier, W.; Shapira-Frommer, R.; Safra, T.; et al. Olaparib maintenance therapy in patients with platinum-sensitive relapsed serous ovarian cancer: A preplanned retrospective analysis of outcomes by BRCA status in a randomised phase 2 trial. Lancet Oncol. 2014, 15, 852-861. [CrossRef]

13. Dougherty, B.A.; Lai, Z.; Hodgson, D.R.; Orr, M.C.M.; Hawryluk, M.; Sun, J.; Yelensky, R.; Spencer, S.K.; Robertson, J.D.; Ho, T.W.; et al. Biological and clinical evidence for somatic mutations in BRCA1 and BRCA2 as predictive markers for olaparib response in high-grade serous ovarian cancers in the maintenance setting. Oncotarget 2017, 8, 43653-43661. [CrossRef] [PubMed] 
14. Cancer Genome Atlas Research Network. Integrated genomic analyses of ovarian carcinoma. Nature 2011, 474, 609-615. [CrossRef] [PubMed]

15. Kaufman, B.; Shapira-Frommer, R.; Schmutzler, R.K.; Audeh, M.W.; Friedlander, M.; Balmaña, J.; Mitchell, G.; Fried, G.; Stemmer, S.M.; Hubert, A.; et al. Olaparib monotherapy in patients with advanced cancer and a germline BRCA1/2 mutation. J. Clin. Oncol. 2015, 33, 244-250. [CrossRef]

16. Pujade-Lauraine, E.; Ledermann, J.A.; Selle, F.; Gebski, V.; Penson, R.T.; Oza, A.M.; Korach, J.; Huzarski, T.; Poveda, A.; Pignata, S.; et al. Olaparib tablets as maintenance therapy in patients with platinum-sensitive, relapsed ovarian cancer and a BRCA1/2 mutation (SOLO2 ENGOT-Ov21): A double-blind, randomised, placebo-controlled, phase 3 trial. Lancet Oncol. 2017, 18, 1274-1284. [CrossRef]

17. Moore, K.; Colombo, N.; Scambia, G.; Kim, B.G.; Oaknin, A.; Friedlander, M.; Lisyanskaya, A.; Floquet, A.; Leary, A.; Sonke, G.S.; et al. Maintenance Olaparib in Patients with Newly Diagnosed Advanced Ovarian Cancer. N. Engl. J. Med. 2018, 379, 2495-2505. [CrossRef]

18. Fong, P.C.; Yap, T.A.; Boss, D.S.; Carden, C.P.; Mergui-Roelvink, M.; Gourley, C.; De Greve, J.; Lubinski, J.; Shanley, S.; Messiou, C.; et al. Poly(ADP)-ribose polymerase inhibition: Frequent durable responses in $B R C A$ carrier ovarian cancer correlating with platinum-free interval. J. Clin. Oncol. 2010, 28, 2512-2519. [CrossRef]

19. Audeh, M.W.; Carmichael, J.; Penson, R.T.; Friedlander, M.; Powell, B.; Bell-McGuinn, K.M.; Scott, C.; Weitzel, J.N.; Oaknin, A.; Loman, N.; et al. Oral poly(ADP-ribose) polymerase inhibitor olaparib in patients with $B R C A 1$ or BRCA2 mutations and recurrent ovarian cancer: A proof-of-concept trial. Lancet 2010, 376, 245-251. [CrossRef]

20. Gelmon, K.A.; Tischkowitz, M.; Mackay, H.; Swenerton, K.; Robidoux, A.; Tonkin, K.; Hirte, H.; Huntsman, D.; Clemons, M.; Gilks, B.; et al. Olaparib in patients with recurrent high-grade serous or poorly differentiated ovarian carcinoma or triple-negative breast cancer: A phase 2, multicentre, open-label, non-randomised study. Lancet Oncol. 2011, 12, 852-861. [CrossRef]

21. Kaye, S.B.; Lubinski, J.; Matulonis, U.; Ang, J.E.; Gourley, C.; Karlan, B.Y.; Amnon, A.; Bell-McGuinn, K.M.; Chen, L.M.; Friedlander, M.; et al. Phase II, open-label, randomized, multicenter study comparing the efficacy and safety of olaparib, a poly (ADP-ribose) polymerase inhibitor, and pegylated liposomal doxorubicin in patients with BRCA1 or BRCA2 mutations and recurrent ovarian cancer. J. Clin. Oncol. 2012, 30, 372-379. [CrossRef] [PubMed]

22. Liu, J.F.; Barry, W.T.; Birrer, M.; Lee, J.M.; Buckanovich, R.J.; Fleming, G.F.; Rimel, B.; Buss, M.K.; Nattam, S.; Hurteau, J.; et al. Combination cediranib and olaparib versus olaparib alone for women with recurrent platinum-sensitive ovarian cancer: A randomised phase 2 study. Lancet Oncol. 2014, 15, 1207-1214. [CrossRef]

23. Oza, A.M.; Cibula, D.; Benzaquen, A.O.; Poole, C.; Mathijssen, R.H.; Sonke, G.S.; Colombo, N.; Špaček, J.; Vuylsteke, P.; Hirte, H.; et al. Olaparib combined with chemotherapy for recurrent platinum-sensitive ovarian cancer: A randomised phase 2 trial. Lancet Oncol. 2015, 16, 87-97. [CrossRef]

24. Olaparib Treatment in Relapsed Germline Breast Cancer Susceptibility Gene (BRCA) Mutated Ovarian Cancer Patients Who Have Progressed at Least 6 Months after Last Platinum Treatment and Have Received at Least 2 Prior Platinum Treatments (SOLO3). Available online: https://Clinicaltrials.gov/ct2/show/NCT02282020 (accessed on 22 April 2019).

25. A Study to Examine Olaparib Maintenance Retreatment in Patients with Epithelial Ovarian Cancer (OReO). Available online: https://Clinicaltrials.gov/ct2/show/NCT03106987 (accessed on 22 April 2019).

26. Platine, Avastin and OLAparib in 1st Line (PAOLA-1). Available online: https://Clinicaltrials.gov/ct2/show/ NCT02477644 (accessed on 22 April 2019).

27. Cediranib Maleate and Olaparib or Standard Chemotherapy in Treating Patients with Recurrent Platinum-Resistant or -Refractory Ovarian, Fallopian Tube, or Primary Peritoneal Cancer. Available online: https://Clinicaltrials.gov/ct2/show/NCT02502266 (accessed on 22 April 2019).

28. Olaparib or Cediranib Maleate and Olaparib Compared with Standard Platinum-Based Chemotherapy in Treating Patients with Recurrent Platinum-Sensitive Ovarian, Fallopian Tube, or Primary Peritoneal Cancer. Available online: https://Clinicaltrials.gov/ct2/show/NCT02446600 (accessed on 22 April 2019).

29. Cediranib Maleate and Olaparib in Treating Patients with Recurrent Ovarian, Fallopian Tube, or Peritoneal Cancer or Recurrent Triple-Negative Breast Cancer. Available online: https://Clinicaltrials.gov/ct2/show/ NCT01116648 (accessed on 22 April 2019). 
30. Sandhu, S.K.; Schelman, W.R.; Wilding, G.; Moreno, V.; Baird, R.D.; Miranda, S.; Hylands, L.; Riisnaes, R.; Forster, M.; Omlin, A.; et al. The poly(ADP-ribose) polymerase inhibitor niraparib (MK4827) in BRCA mutation carriers and patients with sporadic cancer: A phase 1 dose-escalation trial. Lancet Oncol. 2013, 14, 882-892. [CrossRef]

31. Mirza, M.R.; Monk, B.J.; Herrstedt, J.; Oza, A.M.; Mahner, S.; Redondo, A.; Fabbro, M.; Ledermann, J.A.; Lorusso, D.; Vergote, I.; et al. Niraparib Maintenance Therapy in Platinum-Sensitive, Recurrent Ovarian Cancer. N. Engl. J. Med. 2016, 375, 2154-2164. [CrossRef] [PubMed]

32. Moore, K.N.; Secord, A.A.; Geller, M.A.; Miller, D.S.; Cloven, N.; Fleming, G.F.; Wahner Hendrickson, A.E.; Azodi, M.; DiSilvestro, P.; Oza, A.M.; et al. Niraparib monotherapy for late-line treatment of ovarian cancer (QUADRA): A multicentre, open-label, single-arm, phase 2 trial. Lancet Oncol. 2019, 20, 636-648. [CrossRef]

33. A Study of Niraparib Maintenance Treatment in Patients with Advanced Ovarian Cancer Following Response on Front-Line Platinum-Based Chemotherapy. Available online: https://Clinicaltrials.gov/ct2/ show/NCT02655016 (accessed on 22 April 2019).

34. Murai, J.; Huang, S.Y.; Renaud, A.; Zhang, Y.; Ji, J.; Takeda, S.; Morris, J.; Teicher, B.; Doroshow, J.H.; Pommier, Y. Stereospecific PARP trapping by BMN 673 and comparison with olaparib and rucaparib. Mol. Cancer Ther. 2014, 13, 433-443. [CrossRef]

35. Kristeleit, R.; Shapiro, G.I.; Burris, H.A.; Oza, A.M.; LoRusso, P.; Patel, M.R.; Domchek, S.M.; Balmaña, J.; Drew, Y.; Chen, L.M.; et al. A Phase I-II Study of the Oral PARP Inhibitor Rucaparib in Patients with Germline BRCA1/2-Mutated Ovarian Carcinoma or Other Solid Tumors. Clin. Cancer Res. 2017, 23, 4095-4106. [CrossRef]

36. Swisher, E.M.; Lin, K.K.; Oza, A.M.; Scott, C.L.; Giordano, H.; Sun, J.; Konecny, G.E.; Coleman, R.L.; Tinker, A.V.; O'Malley, D.M.; et al. Rucaparib in relapsed, platinum-sensitive high-grade ovarian carcinoma (ARIEL2 Part 1): An international, multicentre, open-label, phase 2 trial. Lancet Oncol. 2017, 18, $75-87$. [CrossRef]

37. Swisher, E.M.; Harrell, M.I.; Lin, K.; Coleman, R.L.; Konecny, G.E.; Tinker, A.V.; O’Malley, D.M.; McNeish, I.; Kaufmann, S.H. BRCA1 and RAD51C promoter hypermethylation confer sensitivity to the PARP inhibitor rucaparib in patients with relapsed, platinum-sensitive ovarian carcinoma in ARIEL2 Part 1. Gynecol. Oncol. 2017, 145, S5. [CrossRef]

38. Konecny, G.E.; Oza, A.M.; Tinker, A.V.; Coleman, R.L.; O’Malley, D.M.; Maloney, L.; Wride, K.; Rolfe, L.; McNeish, I.; Swisher, E.M. Rucaparib in patients with relapsed, primary platinum-sensitive high-grade ovarian carcinoma with germline or somatic BRCA mutations: Integrated summary of efficacy and safety from the phase 2 study ARIEL2 (NCT01891344). Gynecol. Oncol. 2017, 145, S2. [CrossRef]

39. Oza, A.M.; Tinker, A.V.; Oaknin, A.; Shapira-Frommer, R.; McNeish, I.A.; Swisher, E.M.; Ray-Coquard, I.; Bell-McGuinn, K.; Coleman, R.L.; O'Malley, D.M.; et al. Antitumor activity and safety of the PARP inhibitor rucaparib in patients with high-grade ovarian carcinoma and a germline or somatic BRCA1 or BRCA2 mutation: Integrated analysis of data from Study 10 and ARIEL2. Gynecol. Oncol. 2017, 147, 267-275. [CrossRef] [PubMed]

40. Coleman, R.L.; Oza, A.M.; Lorusso, D.; Aghajanian, C.; Oaknin, A.; Dean, A.; Colombo, N.; Weberpals, J.I.; Clamp, A.; Scambia, G.; et al. Rucaparib maintenance treatment for recurrent ovarian carcinoma after response to platinum therapy (ARIEL3): A randomised, double-blind, placebo-controlled, phase 3 trial. Lancet 2017, 390, 1949-1961. [CrossRef]

41. A Study of Rucaparib Versus Chemotherapy BRCA Mutant Ovarian, Fallopian Tube, or Primary Peritoneal Cancer Patients. Available online: https://Clinicaltrials.gov/ct2/show/study/NCT02855944 (accessed on 22 April 2019).

42. A Combination Study of Rucaparib and Atezolizumab in Participants with Advanced Gynecologic Cancers and Triple-Negative Breast Cancer. Available online: https:/Clinicaltrials.gov/ct2/show/NCT03101280 (accessed on 22 April 2019).

43. Donawho, C.K.; Luo, Y.; Luo, Y.; Penning, T.D.; Bauch, J.L.; Bouska, J.J.; Bontcheva-Diaz, V.D.; Cox, B.F.; DeWeese, T.L.; Dillehay, L.E.; et al. ABT-888, an orally active poly(ADP-ribose) polymerase inhibitor that potentiates DNA-damaging agents in preclinical tumor models. Clin. Cancer Res. 2007, 13, 2728-2737. [CrossRef] [PubMed] 
44. Coleman, R.L.; Sill, M.W.; Bell-McGuinn, K.; Aghajanian, C.; Gray, H.J.; Tewari, K.S.; Rubin, S.C.; Rutherford, T.J.; Chan, J.K.; Chen, A.; et al. A phase II evaluation of the potent, highly selective PARP inhibitor veliparib in the treatment of persistent or recurrent epithelial ovarian, fallopian tube, or primary peritoneal cancer in patients who carry a germline BRCA1 or BRCA2 mutation-An NRG Oncology Gynecologic Oncology Group study. Gynecol. Oncol. 2015, 137, 386-391.

45. Puhalla, S.; Beumer, J.H.; Pahuja, S.; Appleman, L.J.; Tawbi, H.A.H.; Stoller, R.G.; Lee, J.J.; Lin, Y.; Kiesel, B.; $\mathrm{Yu}$, J.; et al. Final results of a phase 1 study of single-agent veliparib (V) in patients (pts) with either $B R C A 1 / 2$-mutated cancer $(B R C A+)$, platinum-refractory ovarian, or basal-like breast cancer $(B R C A$-wt). J. Clin. Oncol. 2014, 32, 2570. [CrossRef]

46. Steffensen, K.D.; Adimi, P.; Jakobsen, A. Veliparib Monotherapy to Patients With BRCA Germ Line Mutation and Platinum-Resistant or Partially Platinum-Sensitive Relapse of Epithelial Ovarian Cancer: A Phase I II Study. Int. J. Gynecol. Cancer 2017, 27, 1842-1849. [CrossRef]

47. Kummar, S.; Oza, A.M.; Fleming, G.F.; Sullivan, D.M.; Gandara, D.R.; Naughton, M.J.; Villalona-Calero, M.A.; Morgan, R.J., Jr.; Szabo, P.M.; Youn, A.; et al. Randomized Trial of Oral Cyclophosphamide and Veliparib in High-Grade Serous Ovarian, Primary Peritoneal, or Fallopian Tube Cancers, or BRCA-Mutant Ovarian Cancer. Clin. Cancer Res. 2015, 21, 1574-1582. [CrossRef]

48. Kummar, S.; Chen, A.; Ji, J.; Zhang, Y.; Reid, J.M.; Ames, M.; Jia, L.; Weil, M.; Speranza, G.; Murgo, A.J. Phase I study of PARP inhibitor ABT-888 in combination with topotecan in adults with refractory solid tumors and lymphomas. Cancer Res. 2011, 71, 5626-5634. [CrossRef]

49. Veliparib With Carboplatin and Paclitaxel and as Continuation Maintenance Therapy in Subjects with Newly Diagnosed Stage III or IV, High-grade Serous, Epithelial Ovarian, Fallopian Tube, or Primary Peritoneal Cancer. Available online: https://Clinicaltrials.gov/ct2/show/NCT02470585 (accessed on 22 April 2019).

50. Reiss, K.A.; Herman, J.M.; Zahurak, M.; Brade, A.; Dawson, L.A.; Scardina, A.; Joffe, C.; Petito, E.; Hacker-Prietz, A.; Kinders, R.J.; et al. A Phase I study of veliparib (ABT-888) in combination with low-dose fractionated whole abdominal radiation therapy in patients with advanced solid malignancies and peritoneal carcinomatosis. Clin. Cancer Res. 2015, 21, 68-76. [CrossRef]

51. Shen, Y.; Rehman, F.L.; Feng, Y.; Boshuizen, J.; Bajrami, I.; Elliott, R.; Wang, B.; Lord, C.J.; Post, L.E.; Ashworth, A. BMN 673, a novel and highly potent PARP1 2 inhibitor for the treatment of human cancers with DNA repair deficiency. Clin. Cancer Res. 2013, 19, 5003-5015. [CrossRef] [PubMed]

52. De Bono, J.; Ramanathan, R.K.; Mina, L.; Chugh, R.; Glaspy, J.; Rafii, S.; Kaye, S.; Sachdev, J.; Heymach, J.; Smith, D.C. Phase I, Dose-Escalation, Two-Part Trial of the PARP Inhibitor Talazoparib in Patients with Advanced Germline BRCA1/2 Mutations and Selected Sporadic Cancers. Cancer Discov. 2017, 7, 620-629. [CrossRef] [PubMed]

53. Dhawan, M.S.; Bartelink, I.H.; Aggarwal, R.R.; Leng, J.; Zhang, J.Z.; Pawlowska, N.; Terranova-Barberio, M.; Grabowsky, J.A.; Gewitz, A.; Chien, A.J.; et al. Differential Toxicity in Patients with and without DNA Repair Mutations: Phase I Study of Carboplatin and Talazoparib in Advanced Solid Tumors. Clin. Cancer Res. 2017, 23, 6400-6410. [CrossRef] [PubMed]

54. Turner, N.C.; Telli, M.L.; Rugo, H.S.; Mailliez, A.; Ettl, J.; Grischke, E.M.; Mina, L.A.; Balmaña, J.; Fasching, P.A.; Hurvitz, S.A.; et al. A Phase II Study of Talazoparib after Platinum or Cytotoxic Nonplatinum Regimens in Patients with Advanced Breast Cancer and Germline BRCA1/2 Mutations (ABRAZO). Clin. Cancer Res. 2019, 25, 2717-2724. [CrossRef] [PubMed]

55. BMN 673 (Talazoparib), an Oral PARP Inhibitor, in People with Deleterious BRCA1/2 Mutation-Associated Ovarian Cancer Who Have Had Prior PARP Inhibitor Treatment. Available online: https:/Clinicaltrials.gov/ ct2/show/NCT02326844 (accessed on 22 April 2019).

56. Javelin Parp Medley: Avelumab Plus Talazoparib In Locally Advanced Or Metastatic Solid Tumors. Available online: https://Clinicaltrials.gov/ct2/show/NCT03330405 (accessed on 22 April 2019).

57. Talazoparib in Treating Patients with Recurrent, Refractory, Advanced, or Metastatic Cancers and Alterations in the BRCA Genes. Available online: https://Clinicaltrials.gov/ct2/show/NCT02286687 (accessed on 22 April 2019).

58. A Study Evaluating Talazoparib in Relapsed Ovarian, Fallopian Tube, and Peritoneal Cancer. Available online: https://Clinicaltrials.gov/ct2/show/NCT02836028 (accessed on 22 April 2019). 
59. A Trial of ABT-888 in Combination with Temozolomide Versus Pegylated Liposomal Doxorubicin Alone in Ovarian Cancer. Available online: https:/Clinicaltrials.gov/ct2/show/NCT01113957 (accessed on 22 April 2019).

60. Talazoparib in Determining Genetic Effects on Disease Response in Patients with Advanced Ovarian, Fallopian Tube, or Primary Peritoneal Cancer (POSITION). Available online: https://Clinicaltrials.gov/ct2/ show/NCT02316834 (accessed on 22 April 2019).

61. Rouleau, M.; Patel, A.; Hendzel, M.J.; Kaufmann, S.H.; Poirier, G.G. PARP inhibition: PARP1 and beyond. Nat. Rev. Cancer 2010, 10, 293-301. [CrossRef]

62. Asher, G.; Reinke, H.; Altmeyer, M.; Gutierrez-Arcelus, M.; Hottiger, M.O.; Schibler, U. Poly(ADP-ribose) polymerase 1 participates in the phase entrainment of circadian clocks to feeding. Cell 2010, 142, 943-953. [CrossRef]

63. Haddad, M.; Rhinn, H.; Bloquel, C.; Coqueran, B.; Szabó, C.; Plotkine, M.; Scherman, D.; Margaill, I. Anti-inflammatory effects of PJ34, a poly(ADP-ribose) polymerase inhibitor, in transient focal cerebral ischemia in mice. Br. J. Pharmacol. 2006, 149, 23-30. [CrossRef]

64. Korkmaz, A.; Kurt, B.; Yildirim, I.; Basal, S.; Topal, T.; Sadir, S.; Oter, S. Effects of poly(ADP-ribose) polymerase inhibition in bladder damage caused by cyclophosphamide in rats. Exp. Biol. Med. 2008, 233, 338-343. [CrossRef]

65. Martín-Oliva, D.; O’Valle, F.; Muñoz-Gámez, J.A.; Valenzuela, M.T.; Nuñez, M.I.; Aguilar, M.; Ruiz de Almodóvar, J.M.; Garcia del Moral, R.; Oliver, F.J. Crosstalk between PARP-1 and NF-kappaB modulates the promotion of skin neoplasia. Oncogene 2004, 23, 5275-5283.

66. Ohanna, M.; Giuliano, S.; Bonet, C.; Imbert, V.; Hofman, V.; Zangari, J.; Bille, K.; Robert, C.; Bressac-de Paillerets, B.; Hofman, P.; et al. Senescent cells develop a PARP-1 and nuclear factor-\{kappa\}B-associated secretome (PNAS). Genes Dev. 2011, 25, 1245-1261. [CrossRef]

67. Yang, Y.; Ikezoe, T.; Saito, T.; Kobayashi, M.; Koeffler, H.P.; Taguchi, H. Proteasome inhibitor PS-341 induces growth arrest and apoptosis of non-small cell lung cancer cells via the JNK c-Jun AP-1 signaling. Cancer Sci. 2004, 95, 176-180. [CrossRef] [PubMed]

68. Szanto, A.; Hellebrand, E.E.; Bognar, Z.; Tucsek, Z.; Szabo, A.; Gallyas, F., Jr.; Sumegi, B.; Varbiro, G. PARP-1 inhibition-induced activation of PI-3-kinase-Akt pathway promotes resistance to taxol. Biochem. Pharmacol. 2009, 77, 1348-1357. [CrossRef] [PubMed]

69. Ethier, C.; Tardif, M.; Arul, L.; Poirier, G.G. PARP-1 modulation of mTOR signaling in response to a DNA alkylating agent. PLoS ONE 2012, 7, e47978. [CrossRef] [PubMed]

70. Boucher, M.J.; Morisset, J.; Vachon, P.H.; Reed, J.C.; Lainé, J.; Rivard, N. MEK ERK signaling pathway regulates the expression of $\mathrm{Bcl}-2, \mathrm{Bcl}-\mathrm{X}(\mathrm{L})$, and $\mathrm{Mcl}-1$ and promotes survival of human pancreatic cancer cells. J. Cell. Biochem. 2000, 79, 355-369. [CrossRef]

71. Kandala, P.K.; Wright, S.E.; Srivastava, S.K. Blocking epidermal growth factor receptor activation by 3,3'-diindolylmethane suppresses ovarian tumor growth in vitro and in vivo. J. Pharmacol. Exp. Ther. 2012, 341, 24-32. [CrossRef] [PubMed]

72. Brown, J.S.; Sundar, R.; Lopez, J. Combining DNA damaging therapeutics with immunotherapy: More haste, less speed. Br. J. Cancer 2018, 118, 312-324. [CrossRef] [PubMed]

73. Jiao, S.; Xia, W.; Yamaguchi, H.; Wei, Y.; Chen, M.K.; Hsu, J.M.; Hsu, J.L.; Yu, W.H.; Du, Y.; Lee, H.H.; et al. PARP Inhibitor Upregulates PD-L1 Expression and Enhances Cancer-Associated Immunosuppression. Clin. Cancer Res. 2017, 23, 3711-3720. [CrossRef]

74. Stewart, R.A.; Pilié, P.G.; Yap, T.A. Development of PARP and Immune-Checkpoint Inhibitor Combinations. Cancer Res. 2018, 78, 6717-6725. [CrossRef]

75. Zhang, G.; Liu, C.; Bai, H.; Cao, G.; Cui, R.; Zhang, Z. Combinatorial therapy of immune checkpoint and cancer pathways provides a novel perspective on ovarian cancer treatment. Oncol. Lett. 2019, 17, 2583-2591. [CrossRef]

76. Karzai, F.; VanderWeele, D.; Madan, R.A.; Owens, H.; Cordes, L.M.; Hankin, A.; Couvillon, A.; Nichols, E. Activity of durvalumab plus olaparib in metastatic castration-resistant prostate cancer in men with and without DNA damage repair mutations. J. Immunother. Cancer 2018, 6, 141. [CrossRef] 
77. Vinayak, S.; Tolaney, S.M.; Schwartzberg, L.S.; Mita, M.M.; McCann, G.A.-L.; Tan, A.R.; Hendrickson, A.E.-W.; Forero-Torres, A.; Anders, C.K.; Wulf, G.M.; et al. TOPACIO Keynote-162: Niraparib + pembrolizumab in patients (pts) with metastatic triple-negative breast cancer (TNBC), a phase 2 trial. J. Clin. Oncol. 2018, 36, 1011. [CrossRef]

78. Konstantinopoulos, P.A.; Waggoner, S.E.; Vidal, G.A.; Mita, M.M.; Fleming, G.F.; Holloway, R.W.; Van Le, L.; Sachdev, J.C.; Chapman-Davis, E.; Colon-Otero, G.; et al. TOPACIO Keynote-162 (NCT02657889): A phase 12 study of niraparib p pembrolizumab in patients (pts) with advanced triple-negative breast cancer or recurrent ovarian cancer (ROC)—Results from ROC cohort. J. Clin. Oncol. 2018, 36, 106. [CrossRef]

79. Friedlander, M.; Meniawy, T.; Markman, B.; Mileshkin, L.R.; Harnett, P.R.; Millward, M.; Lundy, J.; Freimund, A.E.; Norris, C.; Wu, J.; et al. A phase $1 \mathrm{~b}$ study of the anti-PD-1 monoclonal antibody BGB-A317 (A317) in combination with the PARP inhibitor BGB-290 (290) in advanced solid tumors. J. Clin. Oncol. 2017, 35, 3013. [CrossRef]

80. Chen, Y.; Du, H. The promising PARP inhibitors in ovarian cancer therapy: From Olaparib to others. Biomed. Pharmacother. 2018, 99, 552-560. [CrossRef] [PubMed]

81. Hoeijmakers, J.H. Genome maintenance mechanisms for preventing Cancer. Nature 2001, 411, 366-374. [CrossRef] [PubMed]

82. Bhattacharjee, S.; Nandi, S. Synthetic lethality in DNA repair network: A novel avenue in targeted cancer therapy and combination therapeutics. IUBMB Life 2017, 69, 929-937. [CrossRef] [PubMed]

83. Ghosh, D.; Nandi, S.; Bhattacharjee, S. Combination therapy to checkmate Glioblastoma: Clinical challenges and advances. Clin. Transl. Med. 2018, 7, 33. [CrossRef]

84. Hartwell, L.H.; Szankasi, P.; Roberts, C.J.; Murray, A.W.; Friend, S.H. Integrating genetic approaches into the discovery of anticancer drugs. Science 1997, 278, 1064-1068. [CrossRef]

85. Aymard, F.; Bugler, B.; Schmidt, C.K.; Guillou, E.; Caron, P.; Briois, S.; Iacovoni, J.S.; Daburon, V.; Miller, K.M.; Jackson, S.P.; et al. Transcriptionally active chromatin recruits homologous recombination at DNA double-strand breaks. Nat. Struct. Mol. Biol. 2014, 21, 366-374. [CrossRef]

86. Radhakrishnan, S.K.; Jette, N.; Lees-Miller, S.P. Non-homologous end joining: Emerging themes and unanswered questions. DNA Repair (Amst.) 2014, 17, 2-8. [CrossRef]

87. Bhattacharjee, S.; Nandi, S. Choices have consequences: The nexus between DNA repair pathways and genomic instability in Cancer. Clin. Transl. Med. 2016, 5, 45. [CrossRef] [PubMed]

88. Xiong, X.; Du, Z.; Wang, Y.; Feng, Z.; Fan, P.; Yan, C.; Willers, H.; Zhang, J. 53BP1 promotes microhomology-mediated end-joining in G1-phase cells. Nucleic Acids Res. 2015, 43, 1659-1670. [CrossRef] [PubMed]

89. Arana, M.E.; Seki, M.; Wood, R.D.; Rogozin, I.B.; Kunkel, T.A. Low-fidelity DNA synthesis by human DNA polymerase theta. Nucleic Acids Res. 2008, 36, 3847-3856. [CrossRef] [PubMed]

90. Hogg, M.; Sauer-Eriksson, A.E.; Johansson, E. Promiscuous DNA synthesis by human DNA polymerase $\theta$. Nucleic Acids Res. 2012, 40, 2611-2622. [CrossRef] [PubMed]

91. Roerink, S.F.; van Schendel, R.; Tijsterman, M. Polymerase theta-mediated end joining of replication-associated DNA breaks in C. elegans. Genome Res. 2014, 24, 954-962. [CrossRef] [PubMed]

92. Meyer, D.; Fu, B.X.; Heyer, W.D. DNA polymerases $\delta$ and $\lambda$ cooperate in repairing double-strand breaks by microhomology-mediated end-joining in Saccharomyces cerevisiae. Proc. Natl. Acad. Sci. USA 2015, 112, E6907-E6916. [CrossRef] [PubMed]

93. Ceccaldi, R.; Liu, J.C.; Amunugama, R.; Hajdu, I.; Primack, B.; Petalcorin, M.I.; O'Connor, K.W.; Konstantinopoulos, P.A.; Elledge, S.J.; Boulton, S.J.; et al. Homologous-recombination-deficient tumours are

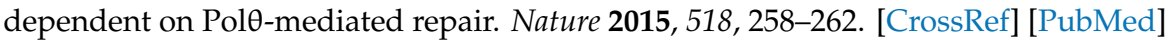

94. Miki, Y.; Swensen, J.; Shattuck-Eidens, D.; Futreal, P.A.; Harshman, K.; Tavtigian, S.; Liu, Q.; Cochran, C.; Bennett, L.M.; Ding, W.; et al. A strong candidate for the breast and ovarian cancer susceptibility gene BRCA1. Science 1994, 266, 66-71. [CrossRef]

95. Wooster, R.; Bignell, G.; Lancaster, J.; Swift, S.; Seal, S.; Mangion, J.; Collins, N.; Gregory, S.; Gumbs, C.; Micklem, G. Identification of the breast cancer susceptibility gene BRCA2. Nature 1995, 378, 789-792. [CrossRef]

96. Chen, S.; Parmigiani, G. Meta-analysis of BRCA1 and BRCA2 penetrance. J. Clin. Oncol. 2007, 25, 1329-1333. [CrossRef] 
97. Farmer, H.; McCabe, N.; Lord, C.J.; Tutt, A.N.; Johnson, D.A.; Richardson, T.B.; Santarosa, M.; Dillon, K.J.; Hickson, I.; Knights, C.; et al. Targeting the DNA repair defect in BRCA mutant cells as a therapeutic strategy. Nature 2005, 434, 917-921. [CrossRef] [PubMed]

98. Lord, C.J.; Ashworth, A. BRCAness revisited. Nat. Rev. Cancer 2016, 16, 110-120. [CrossRef] [PubMed]

99. Wysham, W.Z.; Mhawech-Fauceglia, P.; Li, H.; Hays, L.; Syriac, S.; Skrepnik, T.; Wright, J.; Pande, N.; Hoatlin, M.; Pejovic, T. BRCAness profile of sporadic ovarian cancer predicts disease recurrence. PLoS ONE 2012, 7, e30042. [CrossRef] [PubMed]

100. Zhang, S.; Yuan, Y.; Hao, D. A genomic instability score in discriminating nonequivalent outcomes of $B R C A 1 / 2$ mutations and in predicting outcomes of ovarian cancer treated with platinum-based chemotherapy. PLoS ONE 2014, 9, e113169. [CrossRef] [PubMed]

101. Michels, J.; Vitale, I.; Saparbaev, M.; Castedo, M.; Kroemer, G. Predictive biomarkers for cancer therapy with PARP inhibitors. Oncogene 2014, 33, 3894-3907. [CrossRef] [PubMed]

102. Mukhopadhyay, A.; Elattar, A.; Cerbinskaite, A.; Wilkinson, S.J.; Drew, Y.; Kyle, S.; Los, G.; Hostomsky, Z.; Edmondson, R.J.; Curtin, N.J. Development of a functional assay for homologous recombination status in primary cultures of epithelial ovarian tumor and correlation with sensitivity to poly(ADP-ribose) polymerase inhibitors. Clin. Cancer Res. 2010, 16, 2344-2351. [CrossRef] [PubMed]

103. Bhattacharjee, S.; Nandi, S. Rare Genetic Diseases with Defects in DNA Repair: Opportunities and Challenges in Orphan Drug Development for Targeted Cancer Therapy. Cancers 2018, 10, 298. [CrossRef] [PubMed]

104. Bhattacharjee, S.; Nandi, S. DNA damage response and cancer therapeutics through the lens of the Fanconi Anemia DNA repair pathway. Cell Commun. Signal. 2017, 15, 41. [CrossRef]

105. Brown, L.A.; Kalloger, S.E.; Miller, M.A.; Shih, I.M.; McKinney, S.E.; Santos, J.L.; Swenerton, K.; Spellman, P.T.; Gray, J.; Gilks, C.B.; et al. Amplification of 11q13 in ovarian carcinoma. Genes Chromosom. Cancer 2008, 47, 481-489. [CrossRef]

106. Gunderson, C.C.; Moore, K.N. BRACAnalysis CDx as a companion diagnostic tool for Lynparza. Expert Rev. Mol. Diagn. 2015, 15, 1111-1116. [CrossRef]

107. Abkevich, V.; Timms, K.M.; Hennessy, B.T.; Potter, J.; Carey, M.S.; Meyer, L.A.; Smith-McCune, K.; Broaddus, R.; Lu, K.H.; Chen, J.; et al. Patterns of genomic loss of heterozygosity predict homologous recombination repair defects in epithelial ovarian Cancer. Br. J. Cancer 2012, 107, 1776-1782. [CrossRef] [PubMed]

108. Birkbak, N.J.; Wang, Z.C.; Kim, J.Y.; Eklund, A.C.; Li, Q.; Tian, R.; Bowman-Colin, C.; Li, Y.; Greene-Colozzi, A.; Iglehart, J.D.; et al. Telomeric allelic imbalance indicates defective DNA repair and sensitivity to DNA-damaging agents. Cancer Discov. 2012, 2, 366-375. [CrossRef] [PubMed]

109. Popova, T.; Manié, E.; Rieunier, G.; Caux-Moncoutier, V.; Tirapo, C.; Dubois, T.; Delattre, O.; Sigal-Zafrani, B.; Bollet, M.; Longy, M.; et al. Ploidy and large-scale genomic instability consistently identify basal-like breast carcinomas with BRCA1/2 inactivation. Cancer Res. 2012, 72, 5454-5462. [CrossRef] [PubMed]

110. Telli, M.L.; Timms, K.M.; Reid, J.; Hennessy, B.; Mills, G.B.; Jensen, K.C.; Szallasi, Z.; Barry, W.T.; Winer, E.P.; Tung, N.M.; et al. Homologous Recombination Deficiency (HRD) Score Predicts Response to Platinum-Containing Neoadjuvant Chemotherapy in Patients with Triple-Negative Breast Cancer. Clin. Cancer Res. 2016, 22, 3764-3773. [CrossRef] [PubMed]

111. Jenner, Z.B.; Sood, A.K.; Coleman, R.L. Evaluation of rucaparib and companion diagnostics in the PARP inhibitor landscape for recurrent ovarian cancer therapy. Future Oncol. 2016, 12, 1439-1456. [CrossRef] [PubMed]

112. Norquist, B.M.; Harrell, M.I.; Brady, M.F.; Walsh, T.; Lee, M.K.; Gulsuner, S.; Bernards, S.S.; Casadei, S.; Yi, Q.; Burger, R.A.; et al. Inherited Mutations in Women with Ovarian Carcinoma. JAMA Oncol. 2016, 2, 482-490. [CrossRef] [PubMed]

113. Gunderson, C.C.; Matulonis, U.; Moore, K.N. Management of the toxicities of common targeted therapeutics for gynecologic cancers. Gynecol. Oncol. 2018, 148, 591-600. [CrossRef]

114. Moore, K.; Zhang, Z.Y.; Agarwal, S.; Burris, H.; Patel, M.R.; Kansra, V. The effect of food on the pharmacokinetics of niraparib, a poly(ADP-ribose) polymerase (PARP) inhibitor, in patients with recurrent ovarian Cancer. Cancer Chemother. Pharmacol. 2018, 81, 497-503. [CrossRef]

115. LaFargue, C.J.; Dal Molin, G.Z.; Sood, A.K.; Coleman, R.L. Exploring and comparing adverse events between PARP inhibitors. Lancet Oncol. 2019, 20, e15-e28. [CrossRef]

116. Lynch, T.; Price, A. The effect of cytochrome P450 metabolism on drug response, interactions, and adverse effects. Am. Fam. Physician 2007, 76, 391-396. 
117. Kopin, L.; Lowenstein, C. Dyslipidemia. Ann. Intern. Med. 2017, 167, ITC81-ITC96. [CrossRef] [PubMed]

118. Antolín, A.A.; Mestres, J. Linking off-target kinase pharmacology to the differential cellular effects observed among PARP inhibitors. Oncotarget 2014, 5, 3023-3028. [CrossRef] [PubMed]

119. Francica, P.; Rottenberg, S. Mechanisms of PARP inhibitor resistance in cancer and insights into the DNA damage response. Genome Med. 2018, 10, 101. [CrossRef] [PubMed]

120. Dhillon, K.K.; Swisher, E.M.; Taniguchi, T. Secondary mutations of BRCA1/2 and drug resistance. Cancer Sci. 2011, 102, 663-669. [CrossRef] [PubMed]

121. Norquist, B.; Wurz, K.A.; Pennil, C.C.; Garcia, R.; Gross, J.; Sakai, W.; Karlan, B.Y.; Taniguchi, T.; Swisher, E.M. Secondary somatic mutations restoring $B R C A 1 / 2$ predict chemotherapy resistance in hereditary ovarian carcinomas. J. Clin. Oncol. 2011, 29, 3008-3015. [CrossRef] [PubMed]

122. Chang, H.H.Y.; Pannunzio, N.R.; Adachi, N.; Lieber, M.R. Non-homologous DNA end joining and alternative pathways to double-strand break repair. Nat. Rev. Mol. Cell Biol. 2017, 18, 495-506. [CrossRef] [PubMed]

123. Bunting, S.F.; Callén, E.; Wong, N.; Chen, H.T.; Polato, F.; Gunn, A.; Bothmer, A.; Feldhahn, N.; Fernandez-Capetillo, O.; Cao, L.; et al. 53BP1 inhibits homologous recombination in Brca1-deficient cells by blocking resection of DNA breaks. Cell 2010, 141, 243-254. [CrossRef]

124. Makvandi, M.; Xu, K.; Lieberman, B.P.; Anderson, R.C.; Effron, S.S.; Winters, H.D.; Zeng, C.; McDonald, E.S.; Pryma, D.A.; Greenberg, R.A.; et al. A Radiotracer Strategy to Quantify PARP-1 Expression In Vivo Provides a Biomarker That Can Enable Patient Selection for PARP Inhibitor Therapy. Cancer Res. 2016, 76, 4516-4524. [CrossRef]

125. Panier, S.; Boulton, S.J. Double-strand break repair: 53BP1 comes into focus. Nat. Rev. Mol. Cell Biol. 2014, 15, 7-18. [CrossRef]

126. Konstantinopoulos, P.; Palakurthi, S.; Zeng, Q.; Zhou, S.; Liu, J.F.; Ivanova, E.; Paweletz, C.; Kommajosyula, N.; D’Andrea, A.D.; Shapiro, G.; et al. In vivo synergism between PARP-inhibitor olaparib and HSP90-inhibitor AT13387 in high grade serous ovarian cancer patient derived xenografts. J. Clin. Oncol. 2016, 34, e17045. [CrossRef]

127. Drost, R.; Bouwman, P.; Rottenberg, S.; Boon, U.; Schut, E.; Klarenbeek, S.; Klijn, C.; van der Heijden, I.; van der Gulden, H.; Wientjens, E.; et al. BRCA1 RING function is essential for tumor suppression but dispensable for therapy resistance. Cancer Cell. 2011, 20, 797-809. [CrossRef] [PubMed]

128. Rottenberg, S.; Jaspers, J.E.; Kersbergen, A.; van der Burg, E.; Nygren, A.O.; Zander, S.A.; Derksen, P.W.; de Bruin, M.; Zevenhoven, J.; Lau, A.; et al. High sensitivity of BRCA1-deficient mammary tumors to the PARP inhibitor AZD2281 alone and in combination with platinum drugs. Proc. Natl. Acad. Sci. USA 2008, 105, 17079-17084. [CrossRef] [PubMed]

129. Vaidyanathan, A.; Sawers, L.; Gannon, A.L.; Chakravarty, P.; Scott, A.L.; Bray, S.E.; Ferguson, M.J.; Smith, G. ABCB1 (MDR1) induction defines a common resistance mechanism in paclitaxel- and olaparib-resistant ovarian cancer cells. Br. J. Cancer 2016, 115, 431-441. [CrossRef] [PubMed]

130. Blazek, D.; Kohoutek, J.; Bartholomeeusen, K.; Johansen, E.; Hulinkova, P.; Luo, Z.; Cimermancic, P.; Ule, J.; Peterlin, B.M. The Cyclin K Cdk12 complex maintains genomic stability via regulation of expression of DNA damage response genes. Genes Dev. 2011, 25, 2158-2172. [CrossRef] [PubMed]

131. Johnson, S.F.; Cruz, C.; Greifenberg, A.K.; Dust, S.; Stover, D.G.; Chi, D.; Primack, B.; Cao, S.; Bernhardy, A.J.; Coulson, R.; et al. CDK12 Inhibition Reverses De Novo and Acquired PARP Inhibitor Resistance in BRCA Wild-Type and Mutated Models of Triple-Negative Breast Cancer. Cell Rep. 2016, 17, 2367-2381. [CrossRef] [PubMed]

132. Garcia, T.B.; Snedeker, J.C.; Baturin, D.; Gardner, L.; Fosmire, S.P.; Zhou, C.; Jordan, C.T.; Venkataraman, S.; Vibhakar, R.; Porter, C.C. A Small-Molecule Inhibitor of WEE1, AZD1775, Synergizes with Olaparib by Impairing Homologous Recombination and Enhancing DNA Damage and Apoptosis in Acute Leukemia. Mol. Cancer Ther. 2017, 16, 2058-2068. [CrossRef]

(C) 2019 by the authors. Licensee MDPI, Basel, Switzerland. This article is an open access article distributed under the terms and conditions of the Creative Commons Attribution (CC BY) license (http://creativecommons.org/licenses/by/4.0/). 